\title{
Epithelial-Mesenchymal Transition and Metastasis under the Control of Transforming Growth Factor $\beta$
}

\author{
Yutaro Tsubakihara ${ }^{1,2}$ and Aristidis Moustakas ${ }^{1,2, *(1)}$ \\ 1 Department of Medical Biochemistry and Microbiology, Science for Life Laboratory, Uppsala University, \\ Box 582, SE-751 23 Uppsala, Sweden; yutaro.tsubakihara@imbim.uu.se \\ 2 Ludwig Institute for Cancer Research, Biomedical Center, Uppsala University, Box 595, \\ SE-751 24 Uppsala, Sweden \\ * Correspondence: aris.moustakas@imbim.uu.se; Tel.: +46-18-471-4732
}

Received: 5 October 2018; Accepted: 14 November 2018; Published: 20 November 2018

\begin{abstract}
Metastasis of tumor cells from primary sites of malignancy to neighboring stromal tissue or distant localities entails in several instances, but not in every case, the epithelial-mesenchymal transition (EMT). EMT weakens the strong adhesion forces between differentiated epithelial cells so that carcinoma cells can achieve solitary or collective motility, which makes the EMT an intuitive mechanism for the initiation of tumor metastasis. EMT initiates after primary oncogenic events lead to secondary secretion of cytokines. The interaction between tumor-secreted cytokines and oncogenic stimuli facilitates EMT progression. A classic case of this mechanism is the cooperation between oncogenic Ras and the transforming growth factor $\beta$ (TGF $\beta$ ). The power of TGF $\beta$ to mediate EMT during metastasis depends on versatile signaling crosstalk and on the regulation of successive waves of expression of many other cytokines and the progressive remodeling of the extracellular matrix that facilitates motility through basement membranes. Since metastasis involves many organs in the body, whereas EMT affects carcinoma cell differentiation locally, it has frequently been debated whether EMT truly contributes to metastasis. Despite controversies, studies of circulating tumor cells, studies of acquired chemoresistance by metastatic cells, and several (but not all) metastatic animal models, support a link between EMT and metastasis, with TGF $\beta$, often being a common denominator in this link. This article aims at discussing mechanistic cases where TGF $\beta$ signaling and EMT facilitate tumor cell dissemination.
\end{abstract}

Keywords: epithelial-mesenchymal transition; micro-RNA; non-coding RNA; signal transduction; transcription factor; transforming growth factor $\beta$; tumor invasiveness

\section{Introduction}

Epithelial cells differentiate from stem cells in various tissues and retain the ability to change their differentiation into different lineages, including a transition towards the mesenchymal lineage, best known as the epithelial-mesenchymal transition (EMT; Figure 1) [1,2]. An important aspect in the understanding of EMT has been the transitory nature of this process, which has also been termed plasticity, and naturally implies the ability of mesenchymal cells to undergo an inverse process, the mesenchymal-epithelial transition (MET; Figure 1) [1-3]. In fact, several studies on EMT have proposed the term metastable EMT or hybrid epithelial-mesenchymal intermediate phenotype in order to emphasize the generation of intermediate semi-differentiated forms of cells that can be generated either by epithelial or mesenchymal differentiated cells of origin (Figure 1) [4-7]. The architectural and cell biological similarity between epithelial and endothelial cells of the blood or lymphatic vessels also explains why endothelial cells can undergo endothelial-mesenchymal transition (EndMT) [8,9], however, the contribution of mesenchymal cells towards the generation of endothelial cells is a process 
with few clearly reported cases stemming from organ development, such as the heart and mesenchymal tumors, i.e., sarcomas $[10,11]$. These latter aspects will not be discussed further.

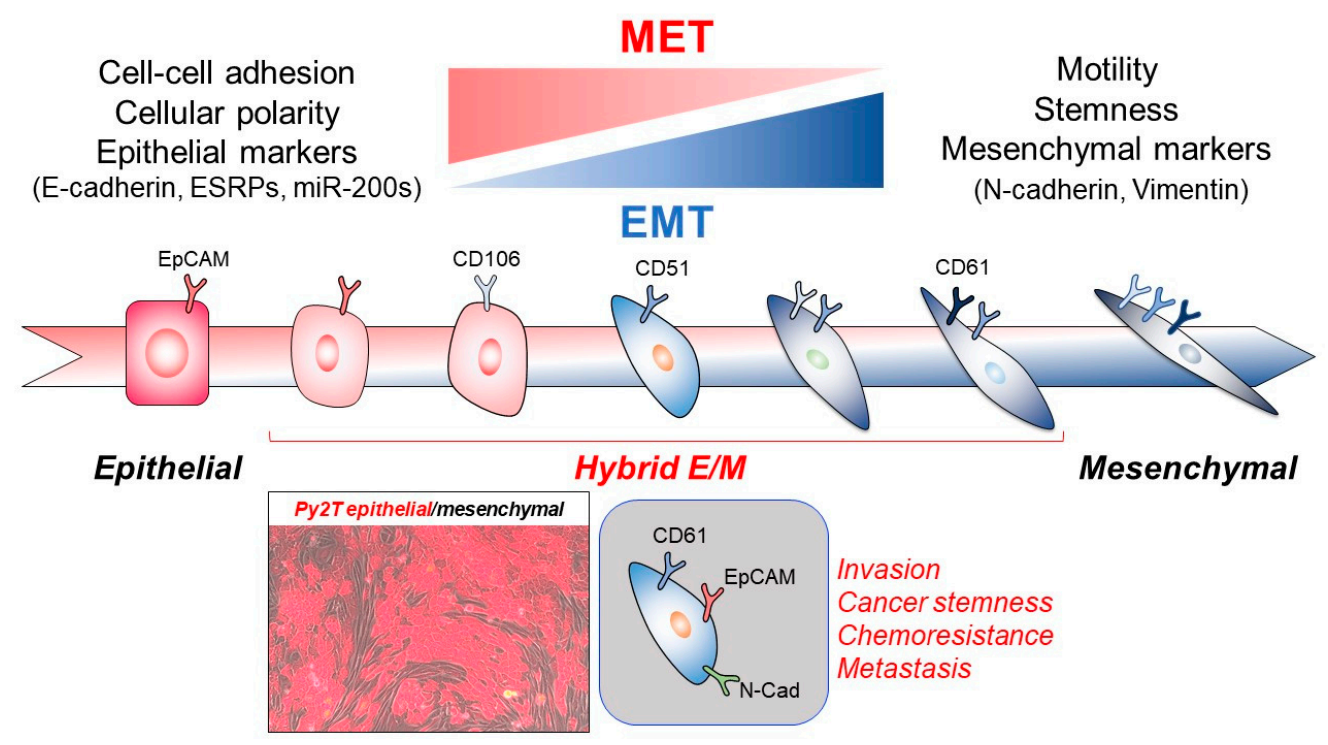

Figure 1. The trajectory of differentiation change is pictorially graphed with epithelial cells on the left, hybrid E/M cells in the middle, and mesenchymal cells on the right hand of the arrow. The EMT and MET are also depicted as gradients of molecular and phenotypic change at the top of the figure and inside the main trajectory. Specific molecular and cellular attributes of epithelial and mesenchymal cells are listed on top of the relevant cell types. Important cell surface antigens are also drawn on the plasma membrane of each cell in a different color, in order to mark the molecular progression from an epithelial to a mesenchymal phenotype and the intermediate stages. At the bottom, the photomicrograph shows a mixed population of epithelial (red) and mesenchymal (dark grey) Py2T mouse breast cancer cells that have undergone EMT followed by MET. An additional cell model depicts a possible hybrid E/M cell that expresses EpCAM, CD61, and N-cadherin (N-Cad) as revealed in certain studies of circulating tumor cells. The features of EMT that are relevant to cancer are listed on the right.

Under most EMT processes in cancer, epithelial cells generate newly synthesized extracellular matrix (ECM) glycoproteins and corresponding cell surface receptors that communicate with the new ECM, generating a new cellular microenvironment that enforces further changes in cell differentiation [1]. Concomitantly, changes in cell-cell adhesion complexes (Figure 1), rendering them looser and more flexible, permit the mobility of single or cohorts of a finite number of tumor cells away from the differentiated epithelium [1]. Changes in cytoskeletal components (microfilaments, intermediate filaments, or even microtubules) drive the disassembly-reassembly of cell-cell contacts and also regulate cell motility (Figure 1), the cell cycle, gene expression, and new exocytosis, contributing to ECM neo-synthesis [1]. Under the MET, similar but not exactly the same reverse phenomena take place, but in general, re-building of epithelial cell-cell contacts (e.g., adherens and tight junctions) and supporting acto-myosin reassembly is a hallmark response of the MET (Figure 1) $[5,6]$.

These changes in cellular architecture and function are usually initiated in response to many growth factors and cytokines. These, sometimes, are induced after the DNA damage response or after the sustained activity of dominant oncogenes that operate in tumor cells. The transforming growth factor $\beta$ (TGF $\beta$ ), receptor tyrosine kinase (RTK), the Wnt, Notch, hedgehog, hippo, the cytokine, and nuclear receptor pathways have all been implicated in the onset of EMT [12,13]. Members of the same signaling pathways can also initiate the METs during cancer progression [5,6]. A common feature of the EMT in a large variety of carcinomas is that many of the above signaling pathways crosstalk and share inter-connected regulatory components that play critical roles in the establishment of the EMT or MET. For example, TGF $\beta$ induces the expression of many other growth factors and cytokines, 
which further propagate their signaling activities, while also cooperating with the initial stimulus of TGF $\beta$, generating positive feed-forward loops necessary for sustained signaling that supports the long process of EMT [3,14].

Growth factor and cytokine signaling pathways naturally function by regulating gene expression or by modulating enzymatic activities, processes of degradation or stability and processes of multi-molecular assembly in the cytoplasm, plasma membrane or specific organelles. Among the large number of molecular mechanisms, transcription factors (TF) that promote the EMT (EMT-TFs) have been extensively studied and contributed greatly to the understanding of this process [1]. EMT-TF activity is also coupled to extensive chromatin modification changes, often referred to as epigenetic remodeling, thus contributing to gene regulation, whereas specific splicing factors can also mediate the phenotypic changes outlined above that occur during EMT or MET [3,6]. The families of EMT-TFs include the proteins known as Snail1, Snail2/Slug, zinc finger E-box binding homeobox 1 and 2 (ZEB1 and ZEB2), and members of the Twist family $[1,6]$. These transcription factors have distinct and characteristic DNA-binding or transactivation domains, e.g., zinc-fingers for Snail1, Snail2, both zinc finger and homeodomain for ZEB1/2 and a basic helix loop helix for Twist1-3, acting as DNA-binding domains, yet they seem to regulate a similar set of genes and clearly contribute to the same overall phenotypic process, the EMT.

\section{Regulation of EMT by TGF- $\beta$}

Among the plethora of signaling pathways that induce the EMT in cancer, TGF $\beta$ has been shown to play prominent roles. The term TGF $\beta$ encompasses a large family of secreted polypeptides with diverse developmental and pathophysiological roles [15]; here we mainly refer to the three TGF $\beta$ isoforms, TGF $\beta 1$, TGF $\beta 2$, and TGF $\beta 3$. However, it is worth noting that other family members such as activins, nodal, or bone morphogenetic proteins (BMPs) can regulate either EMT or MET in the context of cancer. We will unfortunately not expand on these alternative growth factors and their mechanisms of action. The TGF $\beta$ family members are dimeric and disulfide-linked extracellular proteins deposited in the ECM of many tissues, including calcified bone, or in the secretory granules of various cells, including platelets, as latent, inactive proteins [16]. Mature TGF $\beta$ ligands are generated when various cell types get activated in the tissue microenvironment, and upon secretion of specific proteases and subsequent expression of integrin receptors, they enforce the chemical cleavage and conformational distortion of the latent ligands [17]. The active dimeric TGF $\beta$ can associate with transmembrane receptors known as type II and type I TGF $\beta$ receptors that act as protein kinases and phosphorylate cytoplasmic proteins on serine, threonine and less frequently on tyrosine (Figure 2) [13]. TGF $\beta$ ligand, the dimeric type II receptor together with the dimeric type I receptor form hetero-hexameric complexes [13]. The ligand-receptor signals via assembly of adaptor and regulatory proteins on the receptors (e.g., the recruitment and activation of tumor necrosis factor $\alpha$ receptor-associated factor (TRAF) ubiquitin ligases); or via the direct phosphorylation of Smad proteins catalyzed by the type I receptor or via the direct phosphorylation of polarity regulators on the tight junctions of epithelial cells, such as partitioning-defective 6 (Par6), catalyzed by the type II receptor (Figure 2) [15]. Receptor-activated (R-) Smads, Smad2, and Smad3 oligomerize with Smad4 and bind to DNA motifs or to many transcription factors, inducing or repressing the expression of genes, which regulate among other cellular processes, the EMT (Figure 2) [14]. The TRAF and other adaptors lead to either the activation of mitogen-activated protein (MAP) kinases or translocation of the cytoplasmic portion of the type I receptor after proteolytic cleavage to the nucleus, eliciting, like the Smad complexes, gene responses that facilitate the EMT $[18,19]$. This central TGF $\beta$ signaling pathway can be negatively regulated by several mechanisms. The inhibitory (I-) Smads, Smad6, and Smad7, whose expression can be induced by TGF $\beta$, prominently act and mediate ubiquitination and lysosomal degradation of the type I receptor or inactivate R-Smad/Smad4 complexes in the nucleus $[15,16]$. The I-Smads mediate recruitment of TRAF ubiquitin ligases to the type I receptor and 
induce MAP-kinase signaling prior to receptor degradation $[18,20]$. In this manner, TGF $\beta$ signaling acts on many cell types and, in the context of cancer, it can promote EMT and tumor metastasis [21].

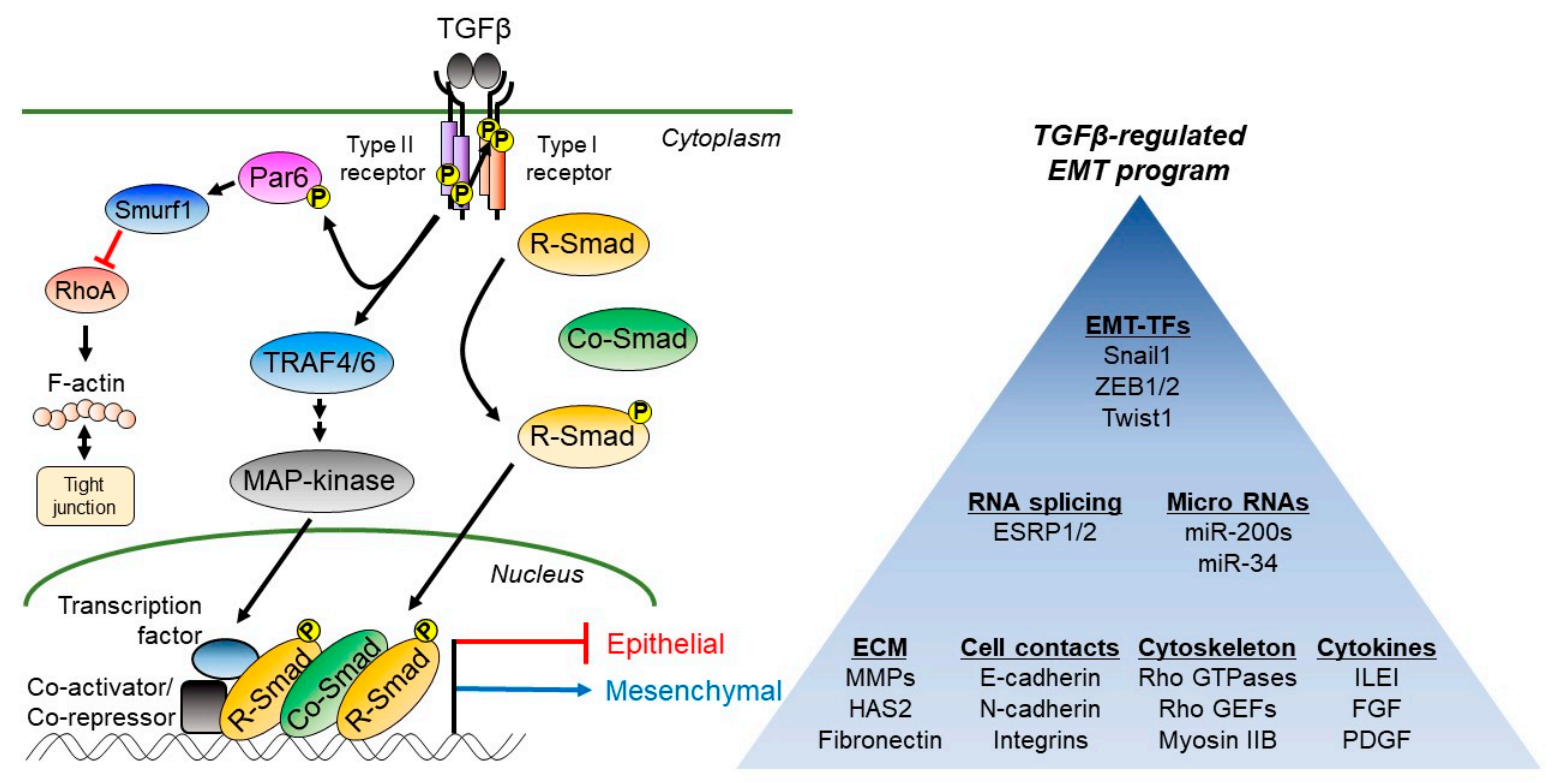

Figure 2. Basic TGF $\beta$ signaling diagram along with a program of TGF $\beta$-regulated genes that contribute to the EMT. Left side, the extracellular dimeric TGF $\beta$ ligand is shown to bind to its plasma membrane receptors, the type II and type I receptors (each drawn as a dimer), causing trans-phosphorylation (circled P) of the type I receptor by the type II receptor. The type II receptor phosphorylates the polarity protein Par6, which recruits the ubiquitin ligase Smurf1 and regulates RhoA-dependent actin assembly and tight junction disassembly. The type I receptor also recruits the ubiquitin ligases TRAF4 and TRAF6, which activate the MAP-kinase pathway by ubiquitination, leading to the transcription factor phosphorylation. The type I receptor kinase also phosphorylates R-Smads, which form complexes with the Co-Smad, Smad4. In the nucleus, Smad complexes and cooperating transcription factors bound to various genes, along with co-repressors (co-activators) either repress the expression of epithelial genes or induce the expression of mesenchymal genes. Right side, a summary of the TGF $\beta$-regulated EMT program divided into seven subprograms, each enlisting only a small representative example of genes that are involved in the EMT and cell motility. Signaling flow is indicated by black arrows (positive flow) and red T-bars (negative regulation); on the gene transcriptional start site, a red T-bar indicates negative regulation and a blue arrow indicates positive regulation of transcription.

The above brief summary emphasizes the general and uniform principles of EMT and their regulation by TGF $\beta$ signaling that apply to all carcinomas studied. In the following sections, specific examples of regulatory mechanisms and individual molecules will be discussed. Readers are advised to consider carefully each example as a unique case that applies to a specific tumor type (always a carcinoma). The combination of in vitro cell-based or in vivo mouse-based models does not necessarily imply that these mechanisms, or the function of a specific molecule, are universally applicable to all cases of observed EMT. The reason of the context-dependent mechanisms in the most part remains unclear and, as a result, we will not attempt to classify the mechanisms according to a hypothetical scheme, proposing that a given mechanism is general or applicable only to some specific experimental models studied. Furthermore, the relevance of in vivo or in vitro EMT-based studies to human cancer pathology requires further detailed analysis.

\subsection{Regulation of ECM Gene Expression by TGF $\beta$}

The ECM changes characteristically during cancer progression. A stiffer ECM, enriched in collagen-based cables that surround the tumor cells and infiltrate the tumor microenvironment, cause a special histology of advanced carcinomas, known as desmoplasia (tissue with excessive, 
fibrotic extracellular matrix, appearing as connective tissue). TGF $\beta$ secreted by tumor cells, associated fibroblasts (cancer-associated fibroblast, CAFs), or immune cells, is capable of inducing new ECM synthesis, ECM remodeling based on the secretion of metalloproteases and phenotypic changes that promote cell invasion [22]. TGF $\beta$, in a time- and dose-dependent manner can induce the expression and stability of several ECM components. Various ECM genes are regulated by the TGF $\beta$ pathway via Smad and MAP-kinase signaling (Figure 2). For example, TGF $\beta$, via Smad, Jun N-terminal kinase (JNK), and p38 MAP-kinase can regulate the expression of MMP2, whereas, via TGF $\beta$-activated kinase 1 (TAK1) signaling, the latter activating nuclear factor $\mathrm{\kappa B}$ (NF- $\mathrm{kB}$ ) induces MMP9 expression [23-25]. Based on such signaling mechanisms, the new ECM is composed of TGF $\beta$-induced fibronectin (FN1), a rather universal response of tissues to TGF $\beta$ signaling, of new collagen isoforms, new matrix metalloproteases (MMPs, MMP2, and MMP9 being most representative), new integrin $\beta$ receptor subunits, and increased levels of plasminogen activator inhibitor 1 (PAI-1), among other matrix constituents [23,26]. The coordinate regulation of MMP and integrin receptor expression is known to contribute to cell migration and the remodeling of the ECM that facilitates epithelial cell invasiveness through the basement membrane.

EMT promotes invasive cell behavior by generating invadopodia on the membrane of the transitioning mesenchymal cells, a process induced by platelet-derived growth factor (PDGF) signaling; Twist1 activation induces PDGF receptor $\alpha$ and mediates PDGF signaling and tumor cell invasiveness [27]. Proteome-wide studies have established a widespread impact of TGF $\beta$ signaling on ECM and cell surface receptor N-linked glycosylation [28]. The specific roles of protein-based glycosylation on mechanisms of EMT remain to be elucidated. Yet, one case feeds back to TGF $\beta$ signaling. This is based on the glycosylating enzymes fucosyl-transferase 3 and 6 , which fucosylate the type I receptor of TGF $\beta$, a modification shown to be required for the EMT response of colorectal cancer cells [29].

The newly synthesized ECM proteins provide cues for cell migration (e.g., fibronectin) but also have signaling capacity. ECM proteins stimulate integrin receptors on the membrane of cancer cells, promoting EMT during breast cancer cell invasion, interestingly, by controlling the release of the active TGF $\beta$ ligand [30]. In prostate cancer cells, ECM-deposited latent TGF $\beta$ can be activated by membrane type I-matrix metalloprotease (MT1-MMP/MMP14), which then induces the secretion of Wnt5a; the sequential action of TGF $\beta$ and Wnt5a sustain EMT and invasiveness of the tumor cells [31]. Not only glycoproteins, but also glycosaminoglycans, such as hyaluronan, can be induced by TGF $\beta$ signaling (Figure 2). Hyaluronan is thought to act as a co-factor in the ECM that facilitates the access of TGF $\beta$ to its receptor complex, thus activating the signaling and expression of Snail1 or Twist1, which promote EMT in cancer cells [32]. In this study, high hyaluronan level in the tumor microenvironment ECM was achieved by the transgenic expression of HAS2, the hyaluronan synthase 2 [32]. It is formally possible that HAS2 acts in a different manner as a signaling protein and its positive actions on EMT may not strictly require extracellular hyaluronan production. This hypothesis is supported by studies of EMT in breast epithelial cells, where TGF $\beta$ induces HAS2 mRNA expression [33]. Extracellular hyaluronan degradation by hyaluronidase or the antibody-mediated block of the major hyaluronan receptor, CD44, failed to inhibit the HAS2-mediated EMT responses [33]. The interplay between ECM molecules and TGF $\beta$ is also confirmed by studies of the impact of ECM stiffness on TGF $\beta$-induced EMT; the EMT required a stiff ECM, whereas a soft ECM led to epithelial cell death instead of the pro-survival signals that maintain the EMT [34]. This observation appears reasonable since TGF $\beta$-activated Smad complexes interact with the transcriptional mediators Yes-associated protein (YAP)/transcriptional coactivator with a PDZ-binding domain (TAZ) (YAP/TAZ) of the Hippo pathway that responds to ECM stiffness, possibly via collagen-dependent plasma membrane receptors, thereby providing another crosstalk mechanism between TGF $\beta$ and another developmental pathway during the process of EMT [35]. 


\subsection{Regulation of Cell Contacts by TGF $\beta$ Signaling}

Loss of adherens junctions is a hallmark of EMT, and TGF $\beta$ can induce E-cadherin loss by transcriptional repression (that requires long-term sustained signaling) of the E-cadherin (CDH1) gene and lysosomal degradation of cell surface E-cadherin, a process contributing to breast cancer metastasis [36]. During EMT, the loss of E-cadherin is often accompanied by gain of N-cadherin (CDH2) expression, which provides new, more flexible cell-cell contacts that are compatible with cancer cell migration (Figure 2) [37]. Additional cadherins undergo expression changes during EMT, as for example is the TGF $\beta$-induced expression of cadherin-11 (osteoblastic cadherin) in lung adenocarcinoma cells [38]. Another mesenchymal cell cadherin induced by TGF $\beta$ during the EMT is cadherin-6 (K-cadherin), which facilitates the invasiveness of thyroid cancer cells [39].

The EMT requires the disassembly of tight junctions, a process usually directly linked to the regulation of polarity complex components. Polarity proteins bind to the cytoplasmic domains of tight junction proteins and assist junctional assembly [40]. By inducing Snail1, TGF $\beta$ achieves downregulation of the polarity regulator Crumbs3 (CRB3), which initiates loss of tight junctions during EMT [41]. Via transcriptional induction of the staphylococcal nuclease and tudor domain containing 1 (SND1) co-activator, expression of the ubiquitin ligase Smad ubiquitylation regulatory factor 1 (Smurf1) is enhanced, causing the degradation of the RhoA small GTPase during EMT [42]. RhoA activity controls actin polymerization near the tight junctions and promotes tight junction assembly; RhoA degradation inversely promotes tight junction disassembly. This transcriptional mechanism is accompanied by a more direct signaling mechanism whereby the TGF $\beta$ type II receptor phosphorylates the polarity adaptor protein Par6, required for the binding of Smurf1 to Par6, which then ubiquitinates and degrades RhoA (Figure 2) [40]. The transcriptional and protein degradation-based mechanisms are further complemented with mechanisms that control mRNA stability and translation. The micro-RNA (miR)-155 inhibits RhoA mRNA translation [43]. In a parallel manner, the partner of Par6 in the polarity complex, Par3, is translationally repressed by the miR-491-5p, whose expression is induced by TGF $\beta$ [44]. It is worth noting here that the regulation of Par6/RhoA by the TGF $\beta$ type II receptor and Smurf1 is coupled to the ubiquitination and lysosomal degradation of the TGF $\beta$ receptor complex by coordinate actions of Smurf1 and Smurf2 [40]. Intriguingly, an independent mechanism achieves similar outcomes during EMT. TGF $\beta$ /Smad and MAP-kinase signaling transcriptionally induce expression of the salt-inducible kinase 1 (SIK1), a member of the AMP-regulated protein kinases; SIK1 associates with Smad7 and recruits Smurf 2 to the TGF $\beta$ type I receptor, promoting its ubiquitination and lysosomal degradation $[45,46]$. Simultaneously, SIK1 associates with Par3 and promotes its phosphorylation and proteasomal degradation, thus facilitating the TGF $\beta$-induced EMT [47]. These examples of Par3 and Par6 negative regulation by TGF $\beta$ signaling during EMT (Figure 2), suggest that in epithelial cells, tight junction disassembly is coupled to TGF $\beta$ receptor internalization and downregulation.

In addition to cell-cell contact remodeling during EMT, TGF $\beta$ promotes integrin receptor-ECM remodeling that facilitates cancer cell motility. During EMT, certain integrins are newly synthesized and other integrins are downregulated. Breast cancer cell EMT induced by TGF $\beta$ and metastasis require the presence of integrin- $\beta 1$ [48]. Complementing integrin function, the adaptor hydrogen peroxide-inducible clone 5 (Hic-5) promotes RhoC small GTPase activity and focal adhesion assembly on mesenchymal cells, required for cell motility via invadopodia [49]. The function of Hic-5 is regulated by TGF $\beta$, which upregulates its expression (possibly via Twist) but also promotes Hic- 5 phosphorylation on tyrosine residues, catalyzed by the Src kinase [49]. The literature on regulation of integrin expression by TGF $\beta$ is extensive and only a few illustrative cases are summarized here.

\subsection{Regulation of the Actin-Based Cytoskeleton during TGF $\beta$-Induced EMT}

As mesenchymal cells are generated by the EMT, ECM and cell adhesion remodeling processes are supported intracellularly by corresponding adaptations of the cytoskeleton, including all of its three major structural groups, microtubules, intermediate and microfilaments. We have already discussed 
the regulation of the RhoA small GTPase that controls actomyosin dynamics in association with tight junction remodeling (Figure 2). Further mechanisms feeding to the regulation of small GTPases during EMT include the transcriptional and miRNA-based regulation of the guanine exchange factor Net1 downstream of TGF $\beta$ (Figure 2) [50]. This is a good example of how complex signal transduction can be. TGF $\beta$ on one hand transcriptionally induces a cytoplasmic Net1 isoform with relatively rapid kinetics; sustained and relatively slower TGF $\beta$ signaling induces a nuclear Net1 isoform together with miR-24, which downregulates cytoplasmic Net1 [50]. This mechanism is thought to regulate distinct RhoA GTPase pools, a cytoplasmic pool possibly regulating tight junction loss during EMT (see above, Figure 2) and a nuclear pool of RhoA possibly mediating the cell cycle arrest of epithelial cells undergoing EMT, as established by independent studies [51,52]. TGF $\beta$ can additionally induce proteasomal degradation of two alternative guanine exchange factors of Rho GTPases during EMT, the leukemia-associated Rho guanine nucleotide exchange factor (LARG), and GEF-H1, a necessary mechanism for the adaptation of mesenchymal cells to integrin signaling mediated by ECM changes associated with cancer cell invasiveness [53]. Focal adhesions of mesenchymal cells generated through EMT are hubs of molecular reactions, such as the TGF $\beta$-induced mobilization of the adaptor protein lipoma preferred partner (LPP) to focal adhesions, which crosslinks actin microfilaments to $\alpha$-actinin and integrin complexes in order to facilitate breast cancer cell motility [54]. Similar mechanisms of actin microfilament-focal adhesion communication involve the adaptor protein moesin [55] and zyxin, the latter being transcriptionally induced by the Twist1 downstream of TGF $\beta$ signaling during the EMT [56]. Increased levels of zyxin regulate the ratio of functional focal adhesions and the resulting motility of lung cancer cells after the EMT [57]. The communication between ECM and actin microfilaments via focal adhesions is functionally dependent on the contractility mediated by myosins; TGF $\beta$ induces expression of myosin IIB by promoting alternative splicing of this protein isoform in breast cancer cells during EMT [58]. The expression of specific myosin isoforms during EMT is thought to contribute to differential patterns of cancer cell motility; accordingly, an ameboid movement can be induced in melanoma cells in response to TGF $\beta$ signaling via transcriptional cooperation of Smad 2 and $\mathrm{Cbp} / \mathrm{p} 300$-interacting transactivator 1 (CITED1) causing the expression of specific myosin light chain isoforms [59]. In most of these examples, motility mechanisms are considered to be activated once the cell-cell contacts are remodeled and the ECM-focal adhesion signaling networks have been stimulated.

\subsection{TGF $\beta$ Controls the Expression of Many Other Growth Factors and Cytokines}

The EMT is a slow cellular process mediated via sequential waves of molecular activity. A large part of such an activity involves multiple growth factors and cytokines, which exhibit tissue-type specificity in various tumors [60]. We discuss some few examples here in order to illustrate this principle and consider cases where TGF $\beta$ is considered the starting point of the cytokine cascade (Figure 2). Crosstalk between TGF $\beta$ and the epidermal growth factor (EGF) is a well-documented case during breast cancer EMT. Accordingly, breast cancer cells undergoing EMT in response to TGF $\beta$ secrete EGF, which signals the activation of the focal adhesion kinase that mediates cytoskeletal remodeling that promotes cell motility [61]. The mitogen-inducible gene 6 (MIG6) is a negative regulator of the EGF receptor, which is under the negative control of miR-200 in epithelial cells; when TGF $\beta$ induces EMT in lung and pancreatic cancer cells, it represses the expression of miR-200, indirectly resulting in the stabilization of MIG6 and a relative inhibition of EGF receptor [62]. Under such relative EGF receptor inhibition, TGF $\beta$ signaling is directed towards the Akt kinase, and gradually the cancer cells acquire resistance to EGF receptor inhibitors such as erlotinib, drug resistance being a phenomenon frequently linked to the process of EMT. Furthermore, TGF $\beta$ can induce the expression of Wnt family and sonic hedgehog (Shh) ligands in hepatocellular or lung adenocarcinoma cells; the action of Wnt or Shh is critical for the establishment of the EMT in these cancer cells under the influence of TGF $\beta[63,64]$. A final case worth citing is the crosstalk between TGF $\beta$ and oncogenic Ras that is dependent on the downstream expression and signaling activity of the PDGF family together with the interleukin-like EMT-inducer (ILEI) (Figure 2). Transgenic mice expressing oncogenic K-Ras 
in their liver develop hepatocellular carcinoma and metastasis that is preceded by EMT enforced by coordinate signaling between K-Ras/MAP-kinase and TGF $\beta$ [65]. In such liver cancer cells, TGF $\beta$ promotes the translation of the ILEI mRNA and ILEI secretion [66], a pro-metastatic cytokine. In response to ILEI, liver cancer cells upregulate their PDGF receptors and downstream signaling via Stat 3 and $\beta$-catenin, whose co-transcriptional complexes enforce stable mesenchymal cells with enhanced metastatic potential [66]. Using this mouse model, combinations of the PDGF receptor and TGF $\beta$ receptor inhibitors were proven effective in limiting the metastatic process, but not the single inhibitors [67], which highlights the modern trend in anti-cancer therapy based on the combinatorial treatment that targets multiple cooperating signaling pathways.

\section{Regulation of EMT-TF Expression and Activity by TGF $\beta$}

As summarized above (Figure 2), the EMT-TFs can transcriptionally repress epithelial genes (e.g., CDH1) and induce mesenchymal genes (e.g., Vimentin, fibronectin (FN1), N-cadherin (CDH2)). In many models of cancer EMT, the high expression of one EMT-TF is accompanied by the induction of two or three additional EMT-TFs in a positive feed-forward manner. Once the contribution of EMT-TFs to EMT was elucidated, several reports established the ability of the same EMT-TFs to induce the generation of cancer stem cells (CSCs) [68]. Snail1 can be induced by TGF $\beta$ via Smad/MAP-kinase signaling that requires the early induction of the embryonic chromatin regulator high mobility group A2 (HMGA2), which then turns on Snail1 expression downstream of TGF $\beta$ [69,70]. Snail1 directly represses epithelial genes such as $C D H 1$ by forming complexes with Smads activated by TGF $\beta$ [71] and through the recruitment of lysine-specific histone demethylase 1 (LSD1/KDM1A) following LSD1-mediated H3K4 demethylation [72-74]. LSD1 physically associates with Snail1 through its Snail/Gfi-1 (SNAG) domain [73] and transcriptional repression can be regulated by the MOF (KAT8) acetyltransferase [75]. MOF acetylates LSD1 to reduce the association of LSD1 with epithelial gene promoters and thus inhibits the pro-EMT actions of Snail1 [75]. Ubiquitination is a dynamic post-translational modification, which is essential for the regulation of protein stability, signal transduction, and DNA repair. Snail1 activity is regulated by the ubiquitin-proteasome system through its phosphorylation by a glycogen synthase kinase $3 \beta$ (GSK3 $\beta$ )-E3 ligase $\beta$-TrCP ( $\beta$-transducin repeats-containing protein) cascade [76]. Conversely, the ubiquitin-editing enzyme A20, which is a key inflammatory and autoimmunity factor whose expression correlates with tumor aggressiveness, stabilizes Snail by mono-ubiquitination of specific Snail1 lysine residues, a mechanism that inhibits GSK3 $\beta$-mediated Snail1 phosphorylation; as a result, A20 facilitates TGF $\beta$-induced EMT in breast cancers [77].

Snail2/Slug can also repress several epithelial genes similar to Snail1. Transcriptional repression by Snail2/Slug is also regulated by epigenetic modifications. The Jumonji domain-containing protein 3 (JMJD3), a histone H3K27 demethylase, which is highly expressed in aggressive hepatocellular carcinoma cells, interacts with Smad3 [78], and catalyzes the transition of H3K27me ${ }^{3}$ and H3K27me ${ }^{2}$ to H3K27me ${ }^{1}$ on the Snail2/Slug promoter, switching the chromatin from a repressive to an active conformation. Consequently, Snail2/Slug is overexpressed and induces EMT [79]. In addition, Snail2/Slug is regulated by post-translational mechanisms during cell cycle progression. Snail2/Slug binds to the promoter of DNA synthesis and checkpoint-related genes, such as Topoisomerase 1 (TOP1), DNA ligase IV, and Rad17 to reduce cell proliferation and delay S-phase progression [80]. During the G1/S transition, Snail2/Slug is phosphorylated at Ser-54 and Ser-104 by cyclin $\mathrm{E} /$ cyclin-dependent kinase 2 (CDK2), whose activity is highest at the $\mathrm{G} 1$ to $S$ phase transition, inducing the ubiquitination-proteasomal degradation of Snail2/Slug [80].

The chromatin silencing factor Bmi1, which is a member of the polycomb-repressive complex 1 (PRC1), is essential for Twist1-induced EMT [81]. Twist1 induces Bmi1 through direct binding to its promoter, whereas Twist1 and Bmi1, in complex, bind to the E-cadherin promoter to induce EMT [81]. Twist1 activity is regulated by the protein kinase Akt1 [82], a member of the highly conserved Akt/PKB serine-threonine kinase family, known to promote tumor initiation and 
progression. Akt1 but not Akt2 or Akt3 interacts with and phosphorylates Twist1 at Ser-42, Thr-121, and Thr-123 to induce $\beta$-TrCP-mediated Twist1 degradation, and inhibit the EMT [82]. Conversely, some of the EMT-TFs are regulated by deubiquitination; ubiquitin chains can be removed from proteins by deubiquitinases (DUBs) also known as ubiquitin-specific protease (USPs). DUB3/USP17 deubiquitinates not only Snail2/Slug and Twist1 but also Smad4 [83] and so, accelerates the EMT by preventing ubiquitin-proteasomal degradation of these important EMT-TFs [84]. In addition, Twist1 can be stabilized by a different mechanism of ubiquitination. Really interesting new gene (RING) finger 8 (RNF8) is a RING finger E3 ligase and involved in DNA repair and telomere end protection, which ubiquitinates Twist1 through K63-linked poly-ubiquitination to sustain and stabilize Twist1 in the nucleus so that Twist1 can elicit the EMT [85]. Twist1 expression is transcriptionally regulated by the Nk2 homeobox 2.8 (Nkx2.8) transcription factor, which is a tumor suppressor; Nkx2.8 directly binds to the Twist1 promoter region and transcriptionally represses its expression, subsequently inhibiting the EMT [86]. Conversely, SRY-related high-mobility-group box 5 (Sox5) facilitates Twist1-induced EMT transcriptionally; TGF $\beta$ induces Sox 5 expression, which binds to the Twist1 promoter and transcriptionally activates its expression to induce the EMT [87].

It is well characterized that ZEB1 and ZEB2 directly repress several epithelial genes and form a double negative feedback loop with the miR-200 family, which are classified as epithelial miRNAs (Figure 3). We discuss the relationship and regulation of EMT by miRNAs in the next section. ZEB1 and ZEB2 are transcriptionally regulated by Fos-related antigen 1 (Fra-1), which is a member of the Fos family of basic leucine zipper domain proteins, dimerized with c-Jun to form the activator protein 1 (AP-1), and negatively correlated with the prognosis of breast cancer patients [88]. Fra-1 binds to putative AP- 1 sites in TGF $\beta 1$ promoter regions to facilitate TGF $\beta$ signaling. Fra- 1 also binds to putative AP-1 sites in the ZEB2 promoter and to an evolutionarily conserved region in intron 1 of ZEB1, increases ZEB1 and ZEB2 expression transcriptionally, and consequently activates TGF $\beta$-induced EMT. Recent studies showed that the Polypyrimidine Tract Binding Protein 3 (PTBP3), which contains four RNA recognition motifs, is involved in miRNA-mediated gene decay and RNA splicing; PTBP3 binds to Argonaute 2 (AGO2), which is the main component of the RNA-induced silencing complex (RISC) and to the 3' UTR of ZEB1 to stabilize the ZEB1 mRNA for EMT induction [89]. In addition to $m i R-200 s$, the epithelial splicing regulatory proteins (ESRPs) exert post-transcriptional regulation of ZEB1 / 2 (Figure 2). The ESRPs are identified as coordinators of the epithelial cell-specific splicing program, and ESRP1/2 are regulated by ZEB1/2 during TGF $\beta$-induced EMT [90]. ZEB1 is regulated post-transcriptionally by the seven in absentia homolog (Siah) family, consisting of Siah1 and Siah2, which are evolutionarily conserved E3 RING finger ubiquitin ligases [91]. In breast epithelial tumors, Siah proteins are highly expressed and induce ubiquitination-proteasomal degradation of ZEB1; once the cells undergo EMT, Siah1/2 expression is decreased, but the mechanism of the decrease of Siah1/2 in mesenchymal cells has not yet been elucidated [91]. ZEB1 transcriptionally regulates ESRP1 expression, which is related to the switching of hyaluronan receptors, from the CD44v to the CD44s isoform [92]. ZEB1 directly binds to the HAS2 promoter and induces HAS2 and hyaluronan synthesis; sequentially, hyaluronan activates the ZEB1 and CD44s expression, which further induces CD44s-mediated ZEB1 expression, proving the existence of a HAS2-hyaluronan-CD44s-ZEB1 positive feed-forward loop [92].

Additional post-transcriptional modifications can regulate TGF $\beta$-Smad signaling and EMT-TF activities. One of these, SUMOylation, is a reversible process similar to ubiquitination, whereby three enzymes, the E1 activating enzymes SAE1/2, the E2 ubiquitin-conjugating enzyme 9 (Ubc9), and the E3 ligases such as the protein inhibitor of activated Stat (PIAS1-4), catalyze the binding of the small ubiquitin-related modifier (SUMO) to lysine residues on target proteins. SUMO and Ubc9 can interact with and induce SUMOylation of Smad4, consequently repressing the transcriptional activity of Smad4 and modulating TGF $\beta$ signaling [93]. ZEB2 interacts with the Cdc42 GTPase-activating protein (CdGAP), which is a major GTPase localized in the nucleus, and which can induce EMT by the direct repression of E-cadherin [94]. ZEB2 activity is also regulated by SUMOylation [93]. 
ZEB2 is SUMOylated at K391 and K866 by the Polycomb protein 2 (Pc2) SUMO E3 ligase, subsequently disrupting the recruitment of the corepressor C-terminal-binding protein (CtBP) to the E-cadherin promoter [95]. By combining the time-course EMT transcriptomic assays with the computational analysis of public cistronic data, three synergistic transcription factors ETS protooncogene 2 (ETS2), hepatocyte nuclear factor 4 (HNF4), and Jun protooncogene B (JUNB) have been identified as regulators of partial EMT, where cancer cells express both epithelial and mesenchymal markers (Figure 1) [96]. These regulators of partial EMT auto-regulate and positively regulate each other by feed-forward loops causing the repression of epithelial E-cadherin and induction of mesenchymal $\mathrm{N}$-cadherin expression [96].

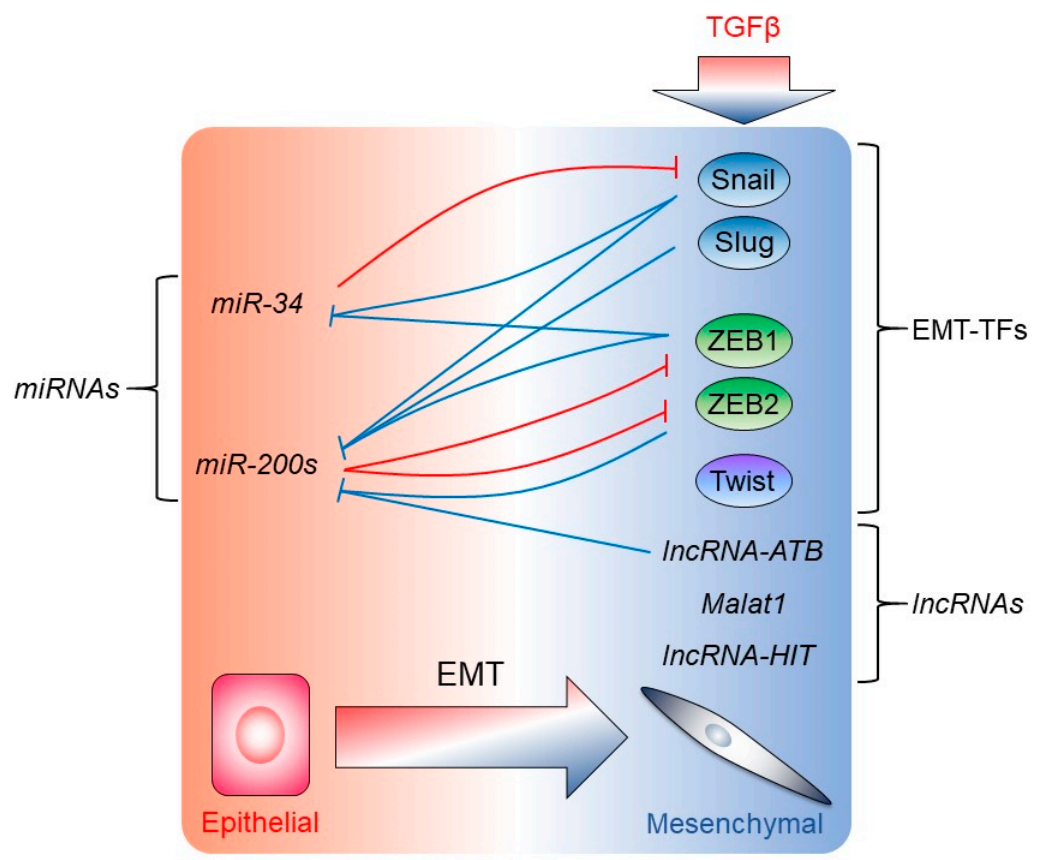

Figure 3. The non-coding RNAs regulate the EMT. Epithelial (left) and mesenchymal (right) genes are listed, the latter being transcriptionally induced by TGF $\beta$ signaling (thick arrow). Thin T-bars indicate the negative regulation of EMT-TFs by miRNAs and inversely, the negative regulation of miRNA expression by the EMT-TFs or $\operatorname{lncRNAs.~Negative~transcriptional~regulation~is~shown~with~blue~T-bars,~}$ whereas negative regulation of mRNA translation and stability by miRNAs is shown with red T-bars.

Compared to the EMT, the reverse process, MET is controlled by relatively unknown molecular mechanisms. Early reports showed that BMP signaling by regulating Id2 (Inhibitor of differentiation 2) expression can induce MET [97]. A hypothesis was put forward suggesting that Id proteins may counteract the function of basic helix-loop-helix EMT-TFs, i.e., Twist or E47, to enforce the MET, requires more direct testing. The Krüppel-like factor 4 (Klf4), which contributes to the generation of induced pluripotent stem cells, inhibits EMT and induces MET through direct interaction with the E-cadherin promoter [98]. Similar to Klf4, Klf10 transcriptionally represses Snail2/Slug expression through direct binding to its promoter and recruitment of histone deacetylase 1 (HDAC1) promoting the MET [99].

\section{Regulation of EMT by miRNAs, IncRNAs, and mRNA Translational Mechanisms}

Several reports have demonstrated that miRNAs play critical roles in cancer malignancy such as EMT and metastasis. The miRNAs are non-coding single-stranded small RNAs (21-25 nucleotides), post-transcriptionally repressing gene expression by sequence-specific interactions with the $3^{\prime}$-untranslated regions (UTRs) of cognate mRNA targets leading to mRNA degradation or inhibition of translation. Among those miRNAs related to the regulation of EMT/MET, the miR-200 and the 
$m i R-34$ families are well characterized and exhibit tumor suppressor functions (Figure 3). The miR-200 family consists of 5 miRNAs (miR-200a, miR-200b, miR-200c, miR-141, and miR-429), encoded by two polycistronic regions, the miR-200b/miR-200a/miR-429 gene and miR-200c/miR-141 gene on chromosome 1 and 12, respectively [100-102]. The miR-200 family is highly expressed in epithelial cells and lower expressed in cells undergone the EMT [100-102]. The miR-200 family forms a double-negative feedback loop with ZEB1/2 controlling the EMT plasticity, whereby miR-200 downregulates ZEB1/2 in epithelial cells and ZEB1/2 repress the expression of miR-200 in mesenchymal cells (Figure 3) [103]. In addition to ZEB1/2, the miR-200 family expression is regulated by Snail1 (Figure 3). Snail1 exhibits bifunctional regulatory mechanisms: Snail1 directly represses miR-200 family expression and induces EMT, conversely Snail1 binds to the ZEB1 promoter region to activate its expression, and consequently, via ZEB1, Snail1 further represses the miR-200 family expression [104]. Snail1, but also Snail2/Slug, repress the miR-200 family expression through CPG methylation on the $m i R-200$ promoter region in dog kidney MDCK cells [105]. In addition to EMT-TFs, the miR-200 family is also epigenetically regulated by fumarate, which is a component of the tricarboxylic acid cycle, metabolized by fumarate hydratase to malate [106]. It has been shown that fumarate inhibits $\alpha$-ketoglutarate-dependent dioxygenases, which are important for histone demethylation [106]. Fumarate inhibits the expression of the miR-200 family by promoting methylation of its promoter region to induce EMT [106]. The second epithelial miR-34 family is also regulated by EMT-TFs (Figure 3). miR-34 forms a double-negative feedback loop with Snail [107]. The miR-34 binds to the $3^{\prime}$ UTR of the Snail1 mRNA to repress its expression; on the other hand, not only Snail1 but ZEB1 can also bind to E-boxes in the miR-34 promoter to repress its expression [107]. Further regulatory mechanisms among EMT-TFs and additional miRNAs are described below.

Apoptosis-stimulating protein of p53-2 (ASPP2) is a haploinsufficient tumor suppressor, which directly interacts with p53 family members and activates pro-apoptotic genes [108]. Hypoxia induces miR-205; miR-205 directly binds to the $3^{\prime}$ UTR of the ASPP2 mRNA to suppress its translation, subsequently inducing the EMT [108]. miR-5003-3p induces EMT through targeting two distinct mRNAs, one being mouse double minute 2 homolog (MDM2), the other being E-cadherin [109]. miR-5003-3p also stabilizes Snail1 protein expression through the direct targeting of MDM2, thus preventing the proteasomal degradation of Snail1 by MDM2, a mechanism that is independent of Snail1 phosphorylation by GSK3 $\beta$ [109]. In addition, miR-5003-3p directly represses the E-cadherin expression, simultaneously inducing the EMT [109]. The $m i R-143$ and $m i R-145$ are known as regulators of MAP-kinases, such as the mitogen-activated protein kinase kinase kinase 2 (MEKK2) [110]. MEKK2 stabilizes the transcriptional regulator TGIF via MAP-kinase-dependent phosphorylation, leading to the activation of TGF $\beta$ /Smad signaling [110]. In addition, these miRNAs play a role in the differentiation of vascular smooth muscle cells from neural crest stem cells and regulate cell motility through TGF $\beta /$ Smad-induced EMT and downregulation of tight junction proteins such as Zonula Occludens (ZO)-1/3 and Occludin [110]. The predicted targets of miR-143 and miR-145 regulate similar functional processes. One of them, CREB1, is the main transcriptional activator of Occludin and is predicted to also have a role in the transcription of ZO-1 [110]. miR-22 has dual functions in cancer as a tumor suppressor and oncogene [111]. Several reports suggest that miR-22 inhibits CREB1 and MYC pathways, through the targeting of CREB regulated transcription coactivator 1 (CRTC1), fms-related tyrosine kinase 3 (FLT3), and Myc binding protein (MYCBP), which are components of these pathways [111]. In addition, $m i R-22$ directly downregulates Snail1 and MAP-kinase 1 (MAPK1/ERK2). ERK2 is a positive regulator of Snail2/Slug activity, which then turns on the expression of Vimentin; thus, miR-22 prevents the EMT by downregulating ERK2 and its downstream Sail2/Slug activity [111]. In prostate cancer, $m i R-3622 a$ expression is inversely correlated to poor survival; miR-3622a expression is repressed by hypermethylation of its promoter region, which classifies miR-3622a as a tumor suppressor [112]. miR-3622a directly binds to the $3^{\prime}$ UTR of the ZEB1 and Snail2/Slug mRNAs to inhibit the EMT [112]. miR-373 is an oncogene that induces EMT; miR-373 binds to the $3^{\prime}$ UTR of the thioredoxin-interacting protein (TXNIP) mRNA, an endogenous inhibitor of 
thioredoxin (Trx) [113]. Trx is important for generating reactive oxygen species (ROS), and its activity is negatively regulated by TXNIP binding to the redox-specific active cysteine residues of Trx [113]. The repression of TXNIP increases Trx activity and ROS levels and stabilizes the hypoxia-inducible factor (HIF) $1 \alpha$. HIF1 $\alpha$ directly binds to the Twist1 promoter to induce Twist1 expression [113]. Twist1 also directly binds to the $m i R-373$ promoter, and as a result, $m i R-373$ activates the HIF1 $\alpha$-Twist 1 pro-EMT axis through the repression of TXNIP [113]. miR-27a prevents the ubiquitin-proteasomal degradation of several EMT-TFs such as Snail1, Snail2/Slug, Twist1, and ZEB2 by the transcriptional repression of Fbxo45 [114]. Fbxo45 is a component of the Skp1-Pam-Fbxo45 complex, which is an atypical ubiquitin E3 ligase, binding to Snail1, Snail2/Slug, Twist1, and ZEB2 through its F-box and SPRY (SPla and the RYanodine Receptor) domains, respectively [114]. Several recent reports show that a hybrid EMT state is important for cancer metastasis as we described earlier (Figure 1); some miRNAs can regulate the hybrid EMT. For example, Twist1-induced miR-424 through binding to the $3^{\prime}$ UTR of the TGFB3 mRNA, induces an intermediate mesenchymal phenotype without obvious E-cadherin repression [115].

In addition to miRNAs, other non-coding RNAs play important roles as regulators of the EMT, including the long non-coding RNAs (lncRNAs), many of which are expressed under the regulatory input of TGF $\beta$ signaling (Figure 3) [116]. This is a rapidly growing area of research and here we summarize a few cases that illustrate important points of regulation. An established function of lncRNAs is to act as "sponges" that base-pair with various miRNAs, thus controlling the availability

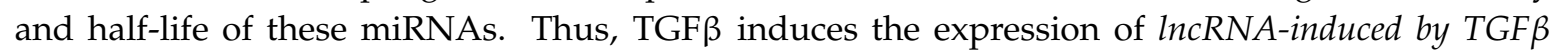
( IncRNA-ATB) in liver cancer cells, which associates with and inactivates miRNAs of the miR-200 family (Figure 3), promoting ZEB1/2 protein expression, once their mRNAs are released from the negative control exerted by the miR-200 members [117]. LncRNA-ATB also regulates liver cancer metastasis beyond its impact on EMT, by positively affecting the expression of the IL-11 protein, an established cytokine with pro-metastatic actions, especially active in the TGF $\beta$-enriched calcified bone tissue where breast or prostate cancer cells often metastasize [117]. In bladder cancer cells, when TGF $\beta$ induces the expression of the lncRNA known as metastasis associated in lung adenocarcinoma transcript-1 (Malat1), the EMT is promoted because this IncRNA assembles into ribonucleoprotein particles together with the PRC2 component and histone methyltransferase suppressor of zeste 12 (Suz12), which thus mediates the well-known repression of E-cadherin [118]. Similar to the action of Malat1 is the function of the IncRNA-HIT (HOXa transcript induced by TGF $\beta$ ), which is transcriptionally induced by TGF $\beta$ signaling and participates in the mechanism of EMT by downregulating E-cadherin [116].

Most previous cases of miRNA action or lncRNA "sponges" are mechanistically based on the regulation of mRNA translation by ribosomes and the control of mRNA stability or decay. TGF $\beta$ signaling can affect mRNA translation through additional mechanisms that implicate protein-based regulation (Figure 2). For example, specific mRNAs contain in their $3^{\prime}$ UTRs conserved motifs that are recognized by trans-acting RNA-binding proteins that control the efficiency of the translation of these mRNAs. Such mRNAs include the cytokine ILEI discussed earlier, the TGF $\beta$ family member inhibin $\beta A$ and the regulator of endocytosis and adaptor protein disabled-2 (Dab2) [119-121]. TGF $\beta$ signaling activates the Akt2 kinase, which phosphorylates the heterogeneous ribonucleoprotein E1 (hnRNPE1); this phosphorylation helps hnRNPE1 to dissociate from the translation elongation factor 1A1 (eEF1A1), which is then released and can promote the synthesis of ILEI or Dab2 protein [119-121]. Thus, binding of the hnRNPE1/eEF1A1 complex on Dab2, inhibin $\beta A$ or ILEI mRNAs inhibits ribosomal subunit assembly necessary for driving protein synthesis. The three proteins discussed here positively mediate the EMT. It is anticipated that this mechanism may encompass the regulation of the synthesis of several proteins, since genome-wide screens performed by mRNA immunoprecipitation followed by sequencing of the mRNA [122] or by microarray analysis of mRNAs selected from the polysome-bound cellular pool [65] have identified a large number of translationally regulated mRNAs during TGF $\beta$-induced EMT. 


\section{The Importance of EMT in Tumor Metastasis}

Patient mortality due to primary tumor development is gradually decreasing thanks to technologies for early diagnosis and drugs with specific molecular targets. However, once a primary tumor metastasizes to distant organs, therapy based on surgery and anti-cancer drug treatment or radiation therapy become very ineffective. Therefore, $90 \%$ of cancer patients die of metastasis without effective treatment. For these reasons, the effective treatment and the elucidation of the mechanisms of metastasis are important $[1,123]$. Metastasis is a complex process involving the action of many cell types in addition to the malignant cells. Once a primary tumor acquires invasive power in a primary site, malignant cells invade the blood vessels (intravasation) [123]. After intravasation, tumor cells move to distant organs through the circulation or the lymphatic system; metastatic cells found in the blood circulation are known as circulating tumor cells (CTCs), and most of such CTCs are eliminated by the immune system, employing primarily dendritic cells and macrophages [123]. However, few of the CTCs can escape destruction by the immune system and metastasize to distant organs. Then, additional cells, including mature platelets, protect the CTCs from further destruction by the immune system and facilitate extravasation [124]. Finally, metastatic cells form secondary tumors at distant organs such as the brain, liver, and bone, in a manner that depends on the tissue origin of the primary tumor.

Expression of the leucine-rich repeat-containing G protein-coupled receptor 4 (Lgr4) in human prostate cancer cell lines correlates with invasiveness and metastatic potential of these cells [125]. Studies in Lgr4 knockout mice showed that prostate cancer development was delayed at an early age, but no effect on tumor formation and cancer cell proliferation could be observed later in their life [125]. In addition, lung metastasis and survival were attenuated in the Lgr4 knockout mice. Ablation of Lgr4 in the prostate cancer cell line DU145 showed that migration, invasion, and EMT-TF expression were decreased, conversely, E-cadherin expression was increased [125]. Thus, Lgr4 plays an essential role in prostate cancer EMT and metastasis [125]. Triple-negative breast cancer (TNBC) is one of the most aggressive breast malignancies. Musculoaponeurotic fibrosarcoma (MAF) oncogene family protein $\mathrm{K}$ (MAFK), a member of the small MAF family of transcription factors, is highly expressed in TNBC, due to induction by TGF $\beta$ [126]. MAFK promotes EMT through transcriptional induction of the transmembrane glycoprotein $\mathrm{nmb}$ (GPNMB) and directly represses E-cadherin expression, subsequently affecting tumor formation, migration, invasion, and metastasis [126]. Lysyl oxidase-like 2 (LOXL2), which is a member of the lysyl oxidase family, and E47, which is one of the basic helix-loop-helix EMT-TFs, interact with each other and directly repress the E-cadherin gene to induce EMT [127]. In addition, LOXL2 and E47 directly regulate FN1 and cytokines such as the tumor necrosis factor- $\alpha(\mathrm{TNF} \alpha)$ and the granulocyte-monocyte colony stimulating factor (GM-CSF), which are required for the formation of the pre-metastatic niche [127]. A screen performed to identify competing endogenous RNAs (ceRNAs) that govern metastasis revealed that the targets of the tumor suppressor miR-181b are integrin $\alpha 1$ (ITGA1) and adenylyl cyclase 9 (ADCY9) [128,129]. At basal levels of expression, $m i R-181 b$ represses both ITGA1 and ADCY9 mRNAs and inhibits the metastatic cascade. However, once ZEB1 induces ITGA1 expression, the high levels of the ITGA1 mRNA preferentially act as a ceRNA ("sponge") for the miR-181b; then ADCY9 protein synthesis is de-repressed and ADCY9-produced cAMP promotes the metastasis cascade [128,129]. Knockout of two EMT-TFs, Snail1 and ZEB1 from metastatic TNBC cells using the CRISPR/Cas9 system revealed a partial reversion towards an epithelial phenotype (MET) and the impact on these two factors on cell proliferation and motility $[130,131]$. These studies strongly suggest that aggressive cancer cells that express multiple EMT-TFs have undergone a long history of EMT-related change. Reversion to a progenitor epithelial cell type may require the removal of all EMT-TFs expressed in a given tumor cell.

The fact that EMT is related to and important for migration, invasion, and metastasis (Figure 1) is supported by many studies [1]. However, reports of carefully designed genetic models in mice have demonstrated that EMT is not required for cancer metastasis but is important for chemoresistance development in pancreatic and breast cancer mouse models [132,133]. Using transgenic EMT reporter mice, which is a triple-transgenic breast cancer mouse model 
(MMTV-PyMT/Rosa26-loxP-RFP-loxP-GFP/Fsp1-Cre) with the following features: the oncogene Polyoma Virus middle $T$ antigen under the direction of the mouse mammary tumor virus (MMTV-PyMT) causes breast tumorigenesis; the Cre-switchable fluorescent marker (loxP-RFP-loxP-GFP) is ubiquitously expressed by the $\beta$-actin promoter of the Rosa 26 locus, whereas the fibroblast-specific protein 1 (Fsp1) promoter drives Cre recombinase expression, causing the loss of RFP and switch on of GFP only in cells that express Fsp1, i.e., mesenchymal cells [132]. Accordingly, epithelial cells express RFP under the control of the $\beta$-actin promoter. Once the cells undergo EMT, the Fsp1 promoter is activated in the early EMT stage and induces Cre recombinase expression, subsequently genetically deleting the RFP cassette. As a result, the fluorescent protein expression switches from RFP to GFP permanently [132]. In other words, once the cells have undergone EMT, they express GFP sustainably. In the EMT reporter mice, spontaneous primary breast tumors were developed and gave rise to lung metastases [132]. The primary breast tumor cells expressed both RFP and GFP, but metastatic tumor cells did not express GFP [132]. This suggested that the metastatic cells did not have to undergo EMT in this model system [132]. In agreement, an independent study used conditional Snail1 and Twist1 knock-out in the pancreatic epithelium of mice, which could spontaneously develop primary pancreatic tumors and metastases to the lung, liver, and spleen due to their Pdx1-Cre-mediated activation of K-Ras and mutant p53 (KPC model) [133]. The knock-out mice showed similar results as the EMT reporter mice, as pancreatic cancer did not show signs of EMT in the metastatic tumors; however, the EMT suppressed the expression of drug transporters, including the equilibrative nucleoside transporter 1 (ENT1) and the concentrating nucleoside transporter 3 (Cnt3), which assisted the metastatic tumor cells to escape from the injection of anti-cancer drugs used to treat the mice [133].

On the other hand, in contrast to the Snail1 and Twist1 knock-outs, ZEB1 knock-out suppressed the metastatic dissemination of primary tumor cells using the same KPC pancreatic cancer model [134]. These reports necessitate a deeper understanding of the contribution of EMT to metastasis, suggesting that the relationship between EMT and metastasis is contextual $[135,136]$. Another case where relatively short distance metastasis that may not necessitate the EMT is when colorectal cancer cells infiltrate and establish metastatic nodules to the peritoneum [137]. Small masses of intestinal epithelial cells disseminate from the growing intestinal tumors in the form of shed epithelial spheres that retain the polarity and architectural organization of the normal tissue [137]. As the tumors disseminate these metastatic outgrowths that pinch off the hyperplastic epithelium, invasive spheroids appear as if the tumor cells have "reverted" their polarity, in other words, they invade by generating spheres made of cells with their apical membranes in the periphery of the sphere, possibly because no basal membrane components are engulfed into the tumor spheres [137]. Such tumor spheres can generate daughter tumor spheres during infiltration of the surrounding peritoneal cavity as a means of propagating their metastatic potential. Unexpectedly, this study proposed that "weak" TGF $\beta$ signaling is required for the generation of tumor spheroids via budding and for the infiltrative dissemination of these tumors [137]. The meaning of "weak" TGF $\beta$ signaling and the mechanism by which tumor tissue delamination is regulated by signaling molecules downstream of TGF $\beta$ remain to be understood.

A possible explanation for some of the controversial findings regarding the impact of EMT on cancer metastasis can be the fact that experimental models usually analyze the impact of "end-stages", i.e., the complete loss of an EMT-TF or high overexpression of an EMT-TF. The new emphasis of an old hypothesis [4], the "metastable" or "hybrid EMT" or "partial EMT" (Figure 1) recently gained some attention and proposed at least partial solutions to the previously analyzed problems [6,7]. Recently, specific cell surface markers identifying the hybrid EMT have been reported. After screening 176 cell surface markers, three markers of hybrid EMT-CD51 (Integrin $\alpha_{\mathrm{v}}$ ), CD61 (Integrin $\beta_{3}$ ) and CD106 (vascular cell adhesion molecule-1, VCAM-1) — were identified [138]. Hybrid EMT can be divided into different states with different patterns of expression of these cell surface markers. In strictly epithelial cells, cancer cells express the typical epithelial marker EpCam without the three above-cell-surface markers [138]. In the early state of EMT, the cells lose EpCam expression with/without CD106 expression (Figure 1). Interestingly, this early EMT state of the cells is thought to be most important 
for providing metastatic ability [138]. Forward to a more mesenchymal state, the cells will express CD51 and CD61 (Figure 1). In their most mesenchymal state, the cells become triple positive for CD51, CD61, and CD106 expression [138]. Xy et al. established a breast tumor-specific Twist1 knock-out mouse model and showed that Twist1 did not affect tumor initiation and primary growth but affected the tumor cell dissemination and metastasis [139]. Twist1-positive cells co-expressed other EMT-TFs, such as Snail1, Snail2/Slug, and ZEB2, and despite this, showed a partial EMT phenotype, which is E-cadherin and Vimentin double-positive. This report also supports the model whereby Twist1-induced partial EMT is important for metastasis [139]. The real picture probably involves a variety of different dissemination scenarios for tumor metastasis; some of these scenarios are clearly based on EMT whereas other scenarios rely more on a partial EMT or not at all on an EMT, suggesting that it will be important to classify tumor metastasis based on the ability of tumor cells to rely or not rely on EMT. Furthermore, partial or hybrid EMT is a concept that may represent the ability of modern technology to detect intermediate phenotypes based on the expression of epithelial and mesenchymal proteins in one and the same cell. Whether such hybrid cells are the key mediators of a specific biological process, such as metastasis in vivo remains unclear. Correlations made though so far provide some strong clues for the importance of a hybrid phenotype. It is also worth considering that hybrid $\mathrm{E} / \mathrm{M}$ cells may be the source of more mesenchymal or more epithelial cells, thus generating heterogeneous populations throughout the long trajectory of metastasis. In the latter dynamic case, it may be impossible to establish cause and effect relationships with specific cell types and the process of metastasis. Rather, correlations of a specific stage in the metastatic cascade and a certain expression pattern of genes and proteins in cells accumulating during this specific stage may be the best that can be achieved by this type of exciting modern cancer research.

In addition to examples where TGF $\beta$-induced EMT or even hybrid EMT may contribute to cancer metastasis, the metastasis literature provides several cases for diverse roles of TGF $\beta$, which are possibly independent of the process of EMT $[21,140]$. Here we briefly summarize a few such cases of tumor metastasis that illustrate diverse mechanisms of action of TGF $\beta$ signaling based on the role of different cell types in the tumor microenvironment. It is well known that Id1 is induced by BMP signaling, but TGF $\beta$ can also induce Id1 in human breast cancer cells [141]. Id1-overexpressing human breast cancer cells (HMLE) showed high tumor-initiating capacity (TIC) and E-cadherin without Vimentin expression (MET). On the other hand, Twist-overexpressing HMLE cells showed TIC but decreased E-cadherin and increased Vimentin expression (EMT). These data suggest that Id1 can induce a TIC phenotype in HMLE cells independently of the induction of EMT [141]. In addition, pulmonary metastases showed a positive correlation between Id1 and epithelial phenotype [141]. Snail or Twist-overexpressing HMLE cells showed the EMT phenotype; combining with Id1 overexpression, Twist-overexpressing cells switched back to the epithelial phenotype (MET), but not Snail-overexpressing cells in vitro and in vivo [141]. These data suggest that TGF $\beta$-induced Id1 expression is important to facilitate MET and promote metastatic colonization in Twist- but not Snail-expressing cells. This is a very good example of what is often referred to as the contextual role of EMT during metastasis.

Several reports suggest that TGF $\beta$ signaling is silenced by several mutations in colorectal cancers (CRCs), but a TGF $\beta$ type I receptor kinase inhibitor prevents CRC metastasis in a mouse model system [142]. By focusing on the contribution of the tumor microenvironment to metastasis, CAFs were identified to secrete TGF $\beta$, which induced IL-11 expression, followed by the activation of GP130/STAT signaling, ending with an enhanced metastatic initiation [142].

Osteolytic bone metastasis from human breast and pancreatic cancer is also inhibited by TGF $\beta$ type I receptor kinase inhibitors $[143,144]$. In the target bone tissue, breast carcinoma cells that extravasate from the bone marrow fenestrated vessels, respond to stromal TGF $\beta$ and turn on the expression of IL-11 and Parathyroid Hormone-Related Protein, which act on osteoblasts and mobilize the secretion of the cytokine RANKL, which finally leads to osteoclast differentiation and activity [143]. The activated osteoclasts destroy mature bone tissue generating a new niche for the metastatic cells [143]. Indirectly, osteoclast activity releases bone matrix-deposited growth factors including TGF $\beta$ s and BMPs, which 
then act on the breast cancer cells and promote a continuous and vicious cycle of signaling that establishes the productive metastatic colonization and secondary tumor growth [143]. By screening for TGF $\beta$-regulated genes in prostate cancer cells, the most highly upregulated gene found was PMEPA1 (prostate transmembrane protein androgen induced-1) [144]. PMEPA1 has three isoforms, PMEPA1a/b/c, PMEPA1a/b containing a membrane-bound domain, and PMEPA1c being cytosolic. Only the membrane-bound domain containing PMEPA1a/b negatively regulated TGF $\beta$ signaling through the recruitment of Smad2/3 and E3 ubiquitin ligases, but the inhibition was not dependent on ubiquitin-proteasomal degradation [144]. In bone metastatic sites, the PMEPA1 gene promoter is epigenetically silenced by methyltransferases and, as a result, TGF $\beta$ signaling is enhanced and assists in the bone metastasis of the pancreatic cancer cells [144]. Another report also suggests that TGF $\beta$ primes human breast cancer cells to lung metastasis through the activation of Angiopoietin-like 4 (ANGPTL4) which disrupts endothelial cell-cell junctions, thus permitting metastatic breast cells to extravasate and initiate metastatic colonies in the lung [145].

Finally, tumor-derived TGF $\beta$ plays key roles in the regulation of the immune system within the tumor microenvironment. Multiple such examples exist [21,140]. An exceptional case that illustrates the diversity of actions TGF $\beta$ can take during metastasis is exemplified by studies of the knockout of the TGF $\beta$ type II receptor gene in breast carcinomas, which become refractory to TGF $\beta$ responses, yet, they oversecrete TGF $\beta$ and chemokines of the CXCL family (SDF-1, CXCL5), which act as chemo-attractants and recruit myeloid cells to the tumor [146]. These myeloid cells then take an active role in helping the invasion and metastasis of the breast carcinoma cells [146].

It is worth noting that in many of the above examples, the mouse models used that exhibit high dependency on TGF $\beta$ signaling also depend on highly aggressive tumor cells, often those with mesenchymal properties (e.g., MDA-MB-231 breast cancer cells or CAFs). Thus, it is not easy to separate TGF $\beta$-regulated metastasis from the mesenchymal fate of tumor cells. Possibly the examples where TGF $\beta$ acts on immune cells may be independent of the effects on EMT, however, even in these cases, the reported experiments measure the expression of mesenchymal markers on the metastatic tumor cells.

Furthermore, modern studies on EMT, epithelial cell polarization, and invasive cell growth are much assisted by the advent of 3D cultures that grow in suspension, in a defined ECM, such as basement membrane-like laminin-enriched matrix or growth factor-enriched matrix (matrigel) or in specially fabricated microfluidic chambers [147-150]. In 3D, tumor cells build a more physiological tissue architecture and signals emanating from growth factors like TGF $\beta$ generate molecular circuits that are much closer to an in vivo situation $[148,150]$. Furthermore, the development of modern microscopic technologies that operate in a non-invasive manner, and the use of the second or third harmonic generation principle, allow for the clear visualization of ECM components, such as collagens, and the direct attachment and movement of tumor cells during invasive growth in vivo [148,151,152]. Such technology, combined with intravital microscopy that permits observation in tumor tissue in the absence of surgery, and in various depths from the skin, provides the unique opportunity to uncover new mechanisms of tumor cell behavior during metastasis [152,153]. It is worth mentioning that the pioneering work on intravital microscopy of metastatic dissemination did indeed observe single-cell invasion and intravasation into blood vessels, a phenotypic feature fully compatible with the process of EMT [152]. However, a combination of intravital microscopy and 3D organoid cultures with a cell-specific marker analysis in Her2 ${ }^{+}$breast cancer cells revealed strong evidence for a hybrid E/M phenotype of early disseminating metastatic cells [154]. An independent technology known as CUBIC is based on the stripping of fat tissue from the whole body of a mouse after formalin-based fixation, providing the unique opportunity of analysis of single cells in every organ of the animal [155]. This method of quantitative analysis with single-cell resolution also provided evidence for a positive role of TGF $\beta$-mediated EMT in cancer metastasis [155]. All these technological advances offer unique opportunities for the classification of different tumor metastasis patterns of dissemination, clarifying the instances under which, full EMT, hybrid or partial EMT and single-cell or collective cell invasion 
are the mechanisms of metastatic spread. Future experiments may combine fate mapping of tumors in mouse models with non-invasive microscopy coupled to single-cell gene expression analysis to reveal unequivocally the reasons why many carcinomas choose the EMT pathways in order to progress into metastasis. In addition, these technologies provide a new means of testing novel drug combinations in a setting that is closer to in vivo case compared to the traditional 2D cell culture on a plastic dish.

\section{New Approaches Towards the Treatment of Metastasis}

Based on all previous discussion, it is logical to think that genetic, protein-based or chemical means that can inhibit the EMT may be a good approach towards the prevention of metastasis. Accordingly, if EMT signals are inhibited, one would expect MET to be induced in cancer cells and an anticipated lower rate of metastasis. However, pioneering studies inspecting the in vivo relevance of MET in mouse models have already suggested that CTCs in which the EMT is partially blocked, exhibit facilitated colonization of distant organs [156,157]. The details of the regulation of hybrid EMT remain largely unknown but gradually become elucidated. In this context, if the early state of hybrid EMT (EpCam negative, CD106 positive cancer cell population [138]), is important for metastatic ability in human malignancies, then approaches targeting this group of cells will have a strong impact in cancer therapy. Focusing on the hybrid E/M-specific cell surface markers (CD51, CD61, and CD106, [138]), and learning more details about the regulation of these cell surface proteins and their functions, might be useful for the development of new diagnostic tools and for the treatment of cancer metastasis. The early EMT phenotype has also been linked to a relative downregulation of two proteasomal subunits ( $\beta 2$ and $\beta 5$ ) as if mesenchymal transition requires lower proteolytic activity in the cell [158]. In agreement, specific proteasome inhibitors with currently active trials as agents against human cancer enhance the EMT response and the pool of breast cancer stem cells, suggesting caution in the use of these inhibitors in cancer therapy [158].

The role of TGF $\beta$ as an inducer of EMT has also brought this pathway in central focus in the anti-cancer drug arena. For example, combinations of highly specific inhibitors targeting the TGF $\beta$ receptor kinase with cytotoxic drugs, such as paclitaxel, effectively blocked the EMT in breast cancer cells and their metastatic potential to colonize the lung [159]. The basic understanding of translational mechanisms that activate pro-EMT factors in response to TGF $\beta$ led to the chemical inhibitor 4Ei-1, which locks the activity of the translation factor eIF4E [160]. 4Ei-1 can inhibit TGF $\beta$-induced EMT primarily because of a drastic reduction in the Snail1 mRNA pool that remains ready for protein synthesis on polysomes, a characteristic phase of an early EMT response [160]. Based on extensive crosstalk between TGF $\beta$ signaling and the tumor suppressor p53, studies using nutlin-3, an established stabilizer of p53 and enhancer of its transcriptional activity, indicated that nutlin-3 can inhibit TGF $\beta$-induced EMT in carcinoma cells; unexpectedly, nutlin-3 reduced the phosphorylation of Smad2 and Smad 3 and suppressed Snail1/Snail2 induction by TGF $\beta$ [161]. This study raised the concern that nutlin-3 may have novel functions by possibly targeting the TGF $\beta$ receptor kinases, which remains to be investigated. On the other hand, the previously established negative role of wild-type and mutant p53 on TGF $\beta$-induced EMT [162] is fully compatible with the studies of nutlin-3 [161]. Another inhibitor of breast cancer cell EMT and Snail1 upregulation induced by TGF $\beta$ is disulfiram, which blocks NF- $\kappa B$ signaling, and which was used to treat organ damage caused by alcohol consumption [163]. How disulfiram inhibits the EMT remains to be analyzed deeper, as well as its potential use as an anti-metastatic drug. In addition, drugs targeting chromatin modifications show promise as anti-EMT agents. The histone deacetylase inhibitor vorinostat could decrease phenotypic changes associated with TGF $\beta$-mediated EMT in vitro and reduced the metastatic potential of biliary tract cancer cells [164]. This chemical inhibitor also reverted to some extent the resistance to cytotoxic therapy that such biliary malignant cells develop [164]. An exciting side observation has indicated that vorinostat reduced the pools of nuclear Smad4 downstream of TGF $\beta$ [164], which is compatible with an acetylation-dependent mechanism of Smad4 export from the nucleus [165]. 
A rather intense recent activity analyzes the anti-metastatic potential of natural compounds abundant in herbs or recipes of classical alternative medicine [166]. One such compound, curcumin, already used to treat malignancy, can shift thyroid cancer cells towards an epithelial phenotype presumably because of a yet uncharacterized anti-TGF $\beta$ mode of action possibly targeting TGF $\beta$ receptor expression and activity [167]. In liver cancer, EMT induced by TGF $\beta$ can be counteracted by sulforaphane, a natural compound abundant in various vegetables, which can reduce ROS levels, raising the possibility of its usefulness as an anti-metastatic compound in addition to its established anti-tumorigenic action [168]. Thus, attempts to generate specific inhibitors of EMT, possibly bypassing the danger of accumulating MET-dependent pro-metastatic side effects, will continue actively, as they carry good potential and promise for the development of clinically useful anti-metastatic drugs.

\section{Concluding Remarks}

The mechanisms that drive the EMT in tumor cells are investigated in greater depth and become gradually understood. Recent efforts to elucidate complete signaling pathways, the role of post-translational modifications of diverse proteins that control the EMT and even non-coding RNAs that synergize with proteins to provide more quantitative control of EMT generate exciting new principles of fundamental cell biological processes. Yet, more remains to be discovered with respect to the process of MET (Figure 1). Although MET is logically thought as a mere reversion of the EMT, the now established concept of partial EMT together with the molecular complexity that governs the step-wise transitions in differentiation propose an equally complex mechanism of MET progression such as the one that initiates the EMT, which is worth elucidating in full detail. More important from the point of view of cancer research remains the clarification and detailed elucidation of the circumstances under which the EMT contributes to the early stages of metastatic dissemination of malignant cells. It is equally necessary to explain to what extent molecular mechanisms of EMT that generate cancer stem cells that promote chemoresistance and favor metastasis, represent distinct processes that may have as common features the action of key molecules, such as specific EMT-TFs, yet are orchestrated by unique sequences of interactions and regulatory steps. An equally important question to resolve is the extent to which the factors that drive the EMT, and whose expression is misregulated in human tumors, as clearly established by transcriptomic screens of many carcinomas and even non-epithelial malignancies, remain expressed in metastatic tumor cells by necessity to sustain a long-term (possibly hybrid E/M) mesenchymal cell. Can the removal of these factors, e.g., Snail1 or ZEB1 or combinations, revert aggressive tumor cells to a less malignant, adenoma-like phenotypic state? Discoveries on mechanisms of differentiation changes during malignant progression are a fruitful territory for the development of more advanced diagnostics and drugs that can silence metastatic potential in cancer.

Acknowledgments: This work was funded by the Ludwig Cancer Research (Uppsala Branch), the Swedish Cancer Society, contract grant number: CAN 2015/438 to A.M., the Swedish Research Council, contract grant number: K2013-66X-14936-10-5 to A.M., the Japan Society for the Promotion of Science (JSPS) and the Kanae Foundation for the Promotion of Medical Science to Y.T. We thank all past and present members of the TGF $\beta$ signaling group for their contributions to the scientific work emanating from our laboratory, and especially Paula Elhorst for the contribution to the collection of a set of references cited in this article. The article, due to space limitations, does not cite all relevant publications. We apologize to those authors whose relevant work has not been included in this review article.

Conflicts of Interest: The authors declare no conflict of interest.

\section{Abbreviations}

4Ei-1 eIF4E inhibitor 1

ADCY9 adenylyl cyclase 9

AGO2 argonaute 2

$\operatorname{Akt}(1,2,3) \quad$ oncogene Akt serine/threonine kinase 1, 2, 3 (alias: protein kinase B, PKB)

AP-1 activator protein 1 


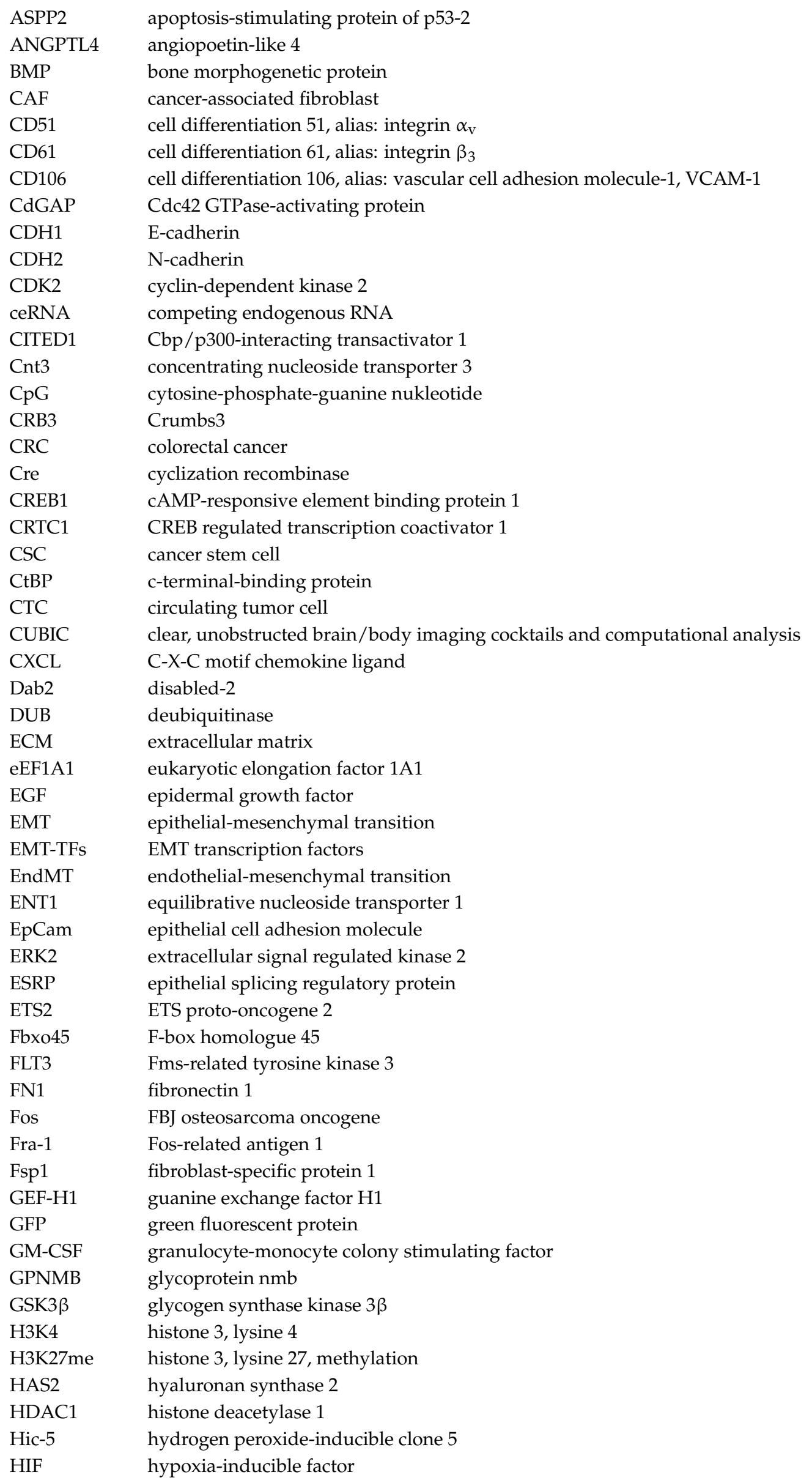


HMGA2 high mobility group A2

HMLE human mammary epithelial cells immortalized with the large T antigen

HNF4 hepatocyte nuclear factor 4

hnRNPE1 heterogeneous ribonucleoprotein E1

Id1/2 inhibitor of differentiation $1 / 2$

IL-11 interleukin 11

ILEI interleukin-like EMT-inducer

I-Smad inhibitory Smad

ITGA1 integrin $\alpha_{1}$

JMJD3 Jumonji domain-containing protein 3

JNK Jun N-terminal kinase

Jun Jun proto-oncogene

Klf4 Krüppel-like factor 4

KPC K-Ras and mutant p53 pancreatic carcinoma mouse model

LARG leukemia-associated Rho guanine nucleotide exchange factor

Lgr4 leucine-rich repeat-containing $G$ protein-coupled receptor 4

lncRNA long non-coding RNA

lncRNA-ATB lncRNA-induced by TGF $\beta$

lncRNA-HIT HOXa transcript induced by TGF $\beta$

LOXL2 lysyl oxidase-like 2

LSD1 lysine-specific histone demethylase 1, alias: KDM1A

MAF musculoaponeurotic fibrosarcoma

MAFK MAF oncogene family protein $\mathrm{K}$

Malat1 metastasis associated in lung adenocarcinoma transcript-1

MAP-kinase mitogen-activated protein kinase

MAPK1 MAP-kinase 1

MDM2 mouse double minute 2 homolog

MEKK2 mitogen-activated protein kinase kinase kinase 2

MET mesenchymal-epithelial transition

MIG6 mitogen-inducible gene 6

MiRNA micro-RNA

MMP matrix metalloprotease

MMTV-PyMT mouse mammary tumor virus polyoma virus middle $\mathrm{T}$ antigen

MOF males absent on the first (alias: KAT8, lysine acetyltransferase 8)

MT1-MMP membrane type I-matrix metalloprotease

MYCBP Myc binding protein

Net1 neuroepithelial cell transforming 1

$\mathrm{NF}-\kappa \mathrm{B} \quad$ nuclear factor- $\mathrm{kB}$

Nkx2.8 Nk2 homeobox 2.8

PAI-1 plasminogen activator inhibitor 1

Par3/6 partitioning-defective 3/6

Pc2 polycomb protein 2

PDGF platelet-derived growth factor

PIAS protein inhibitor of activated Stat

PMEPAI prostate transmembrane protein androgen induced-1

PRC1/2 polycomb-repressive complex 1 and 2

PTBP3 polypyrimidine tract binding protein 3

R-Smad receptor-activated Smad

Rad17 radiation-induced 17 (alias: checkpoint clamp loader component)

RFP red fluorescent protein

Rho Ras homologue

RISC RNA-induced silencing complex

RING really interesting new gene

RNF8 RING finger 8

ROS reactive oxygen species 


$\begin{array}{ll}\text { RTK } & \text { receptor tyrosine kinase } \\ \text { SAE1/2 } & \text { SUMO1 activating enzyme subunit } 1 \\ \text { Shh } & \text { sonic hedegehog } \\ \text { Siah } & \text { seven in absentia homolog } \\ \text { SIK1 } & \text { salt-inducible kinase 1 } \\ \text { Smurf } & \text { Smad ubiquitylation regulatory factor } \\ \text { SND1 } & \text { staphylococcal nuclease and tudor domain containing 1 } \\ \text { SNAG } & \text { Snail1/Gfi-1 } \\ \text { Sox5 } & \text { SRY-related high-mobility-group box 5 } \\ \text { SPRY } & \text { SP1a and the Ryanodine Receptor } \\ \text { Src } & \text { (Rous) sarcoma (virus oncogene) } \\ \text { STAT } & \text { signal transducer and activator of transcription } \\ \text { SUMO } & \text { small ubiquitin-related modifier } \\ \text { Suz12 } & \text { suppressor of zeste 12 } \\ \text { TAK1 } & \text { TGF } \beta \text {-activated kinase 1 } \\ \text { TAZ } & \text { transcriptional coactivator with a PDZ-binding domain } \\ \text { TF } & \text { transcription factor } \\ \text { TGF } \beta & \text { transforming growth factor } \beta \\ \text { TGIF } & \text { TGF } \beta \text {-induced factor homeobox 1 } \\ \text { TIC } & \text { tumor initiating cell } \\ \text { TNBC } & \text { triple-negative breast cancer } \\ \text { TNF } \alpha & \text { tumor necrosis factor- } \alpha \\ \text { TOP1 } & \text { topoisomerase 1 } \\ \text { TRAF } & \text { TNF } \alpha \text { receptor-associated factor } \\ \beta-T r C P & \beta \text {-transducin repeats-containing protein } \\ \text { Trx } & \text { thioredoxin } \\ \text { TXNIP } & \text { thioredoxin-interacting protein } \\ \text { UBC9 } & \text { ubiquitin-conjugating enzyme 9 } \\ \text { USP } & \text { ubiquitin-specific protease } \\ \text { UTR } & \text { untranslated region } \\ \text { Wnt } & \text { wingless and integration site } \\ \text { YAP } & \text { zes-associated protein } \\ \text { ZEB1/2 } & \\ \text { ZO } & \text { zonula occludens } \\ & \end{array}$

\section{References}

1. Nieto, M.A.; Huang, R.Y.; Jackson, R.A.; Thiery, J.-P. EMT 2016. Cell 2016, 166, 21-45. [CrossRef] [PubMed]

2. Kahata, K.; Dadras, M.S.; Moustakas, A. TGF- $\beta$ family signaling in epithelial differentiation and epithelial-mesenchymal transition. Cold Spring Harb. Perspect. Biol. 2018, 10. [CrossRef] [PubMed]

3. Ye, X.; Weinberg, R.A. Epithelial-Mesenchymal Plasticity: A Central Regulator of Cancer Progression. Trends Cell Biol. 2015, 25, 675-686. [CrossRef] [PubMed]

4. Gal, A.; Sjöblom, T.; Fedorova, L.; Imreh, S.; Beug, H.; Moustakas, A. Sustained TGF $\beta$ exposure suppresses Smad and non-Smad signalling in mammary epithelial cells, leading to EMT and inhibition of growth arrest and apoptosis. Oncogene 2008, 27, 1218-1230. [CrossRef] [PubMed]

5. Jolly, M.K.; Ware, K.E.; Gilja, S.; Somarelli, J.A.; Levine, H. EMT and MET: Necessary or permissive for metastasis? Mol. Oncol. 2017, 11, 755-769. [CrossRef] [PubMed]

6. Brabletz, T.; Kalluri, R.; Nieto, M.A.; Weinberg, R.A. EMT in cancer. Nat. Rev. Cancer 2018, 18, $128-134$. [CrossRef] [PubMed]

7. Saitoh, M. Involvement of partial EMT in cancer progression. J. Biochem. 2018, 164, 257-264. [CrossRef] [PubMed]

8. Gonzalez, D.M.; Medici, D. Signaling mechanisms of the epithelial-mesenchymal transition. Sci. Signal. 2014, 7. [CrossRef] [PubMed] 
9. Van Meeteren, L.A.; ten Dijke, P. Regulation of endothelial cell plasticity by TGF- $\beta$. Cell Tissue Res. 2012, 347, 177-186. [CrossRef] [PubMed]

10. Ubil, E.; Duan, J.; Pillai, I.C.; Rosa-Garrido, M.; Wu, Y.; Bargiacchi, F.; Lu, Y.; Stanbouly, S.; Huang, J.; Rojas, M.; et al. Mesenchymal-endothelial transition contributes to cardiac neovascularization. Nature 2014, 514, 585-590. [CrossRef] [PubMed]

11. Li, Y.; Zhong, C.; Liu, D.; Yu, W.; Chen, W.; Wang, Y.; Shi, S.; Yuan, Y. Evidence for Kaposi sarcoma originating from mesenchymal stem cell through KSHV-induced mesenchymal-to-endothelial transition. Cancer Res. 2018, 78, 230-245. [CrossRef] [PubMed]

12. Moustakas, A.; Heldin, C.-H. Signaling networks guiding epithelial-mesenchymal transitions during embryogenesis and cancer progression. Cancer Sci. 2007, 98, 1512-1520. [CrossRef] [PubMed]

13. Derynck, R.; Muthusamy, B.P.; Saeteurn, K.Y. Signaling pathway cooperation in TGF- $\beta$-induced epithelial-mesenchymal transition. Curr. Opin. Cell Biol. 2014, 31, 56-66. [CrossRef] [PubMed]

14. Moustakas, A.; Heldin, C.-H. Induction of epithelial-mesenchymal transition by transforming growth factor ß. Semin. Cancer Biol. 2012, 22, 446-454. [CrossRef] [PubMed]

15. Moustakas, A.; Heldin, C.-H. The regulation of TGF $\beta$ signal transduction. Development 2009, 136, 3699-3714. [CrossRef] [PubMed]

16. Ten Dijke, P.; Arthur, H.M. Extracellular control of TGF $\beta$ signalling in vascular development and disease. Nat. Rev. Mol. Cell Biol. 2007, 8, 857-869. [CrossRef] [PubMed]

17. Travis, M.A.; Sheppard, D. TGF- $\beta$ Activation and Function in Immunity. Annu. Rev. Immunol. 2014, 32, 51-82. [CrossRef] [PubMed]

18. Gudey, S.K.; Wallenius, A.; Landström, M. Regulated intramembrane proteolysis of the TGF $\beta$ type I receptor conveys oncogenic signals. Future Oncol. 2014, 10, 1853-1861. [CrossRef] [PubMed]

19. Mu, Y.; Sundar, R.; Thakur, N.; Ekman, M.; Gudey, S.K.; Yakymovych, M.; Hermansson, A.; Dimitriou, H.; Bengoechea-Alonso, M.T.; Ericsson, J.; et al. TRAF6 ubiquitinates TGF $\beta$ type I receptor to promote its cleavage and nuclear translocation in cancer. Nat. Commun. 2011, 2, 330. [CrossRef] [PubMed]

20. Sorrentino, A.; Thakur, N.; Grimsby, S.; Marcusson, A.; von Bulow, V.; Schuster, N.; Zhang, S.; Heldin, C.-H.; Landström, M. The type I TGF- $\beta$ receptor engages TRAF6 to activate TAK1 in a receptor kinase-independent manner. Nat. Cell Biol. 2008, 10, 1199-1207. [CrossRef] [PubMed]

21. David, C.J.; Massagué, J. Contextual determinants of TGF $\beta$ action in development, immunity and cancer. Nat. Rev. Mol. Cell Biol. 2018, 19, 419-435. [CrossRef] [PubMed]

22. Bellomo, C.; Caja, L.; Moustakas, A. Transforming growth factor $\beta$ as regulator of cancer stemness and metastasis. Br. J. Cancer 2016, 115, 761-769. [CrossRef] [PubMed]

23. Borok, Z. Role for a3 integrin in EMT and pulmonary fibrosis. J. Clin. Investig. 2009, 119, 7-10. [PubMed]

24. Safina, A.; Ren, M.Q.; Vandette, E.; Bakin, A.V. TAK1 is required for TGF- $\beta$ 1-mediated regulation of matrix metalloproteinase-9 and metastasis. Oncogene 2008, 27, 1198-1207. [CrossRef] [PubMed]

25. Sundqvist, A.; Zieba, A.; Vasilaki, E.; Herrera Hidalgo, C.; Soderberg, O.; Koinuma, D.; Miyazono, K.; Heldin, C.-H.; Landegren, U.; ten Dijke, P.; et al. Specific interactions between Smad proteins and AP-1 components determine TGF $\beta$-induced breast cancer cell invasion. Oncogene 2013, 32, 3606-3615. [CrossRef] [PubMed]

26. Javelaud, D.; Mauviel, A. Crosstalk mechanisms between the mitogen-activated protein kinase pathways and Smad signaling downstream of TGF- $\beta$ : Implications for carcinogenesis. Oncogene 2005, 24, 5742-5750. [CrossRef] [PubMed]

27. Eckert, M.A.; Lwin, T.M.; Chang, A.T.; Kim, J.; Danis, E.; Ohno-Machado, L.; Yang, J. Twist1-induced invadopodia formation promotes tumor metastasis. Cancer Cell 2011, 19, 372-386. [CrossRef] [PubMed]

28. Tan, Z.; Lu, W.; Li, X.; Yang, G.; Guo, J.; Yu, H.; Li, Z.; Guan, F. Altered N-Glycan expression profile in epithelial-to-mesenchymal transition of NMuMG cells revealed by an integrated strategy using mass spectrometry and glycogene and lectin microarray analysis. J. Proteome Res. 2014, 13, 2783-2795. [CrossRef] [PubMed]

29. Hirakawa, M.; Takimoto, R.; Tamura, F.; Yoshida, M.; Ono, M.; Murase, K.; Sato, Y.; Osuga, T.; Sato, T.; Iyama, S.; et al. Fucosylated TGF- $\beta$ receptors transduces a signal for epithelial-mesenchymal transition in colorectal cancer cells. Br. J. Cancer 2014, 110, 156-163. [CrossRef] [PubMed]

30. Park, J.; Schwarzbauer, J.E. Mammary epithelial cell interactions with fibronectin stimulate epithelial-mesenchymal transition. Oncogene 2014, 33, 1649-1657. [CrossRef] [PubMed] 
31. Nguyen, H.L.; Kadam, P.; Cao, K.; Wu, S.; Samara, G.J.; Zhang, Q.; Zucker, S.; Cao, J. MT1-MMP Activation of TGF- $\beta$ Signaling Enables Intercellular Activation of an Epithelial-mesenchymal Transition Program in Cancer. Curr. Cancer Drug Targets 2016, 16, 618-630. [CrossRef] [PubMed]

32. Chanmee, T.; Ontong, P.; Mochizuki, N.; Kongtawelert, P.; Konno, K.; Itano, N. Excessive hyaluronan production promotes acquisition of cancer stem cell signatures through the coordinated regulation of Twist and the transforming growth factor $\beta$ (TGF- $\beta$ )-Snail signaling axis. J. Biol. Chem. 2014, 289, 26038-26056. [CrossRef] [PubMed]

33. Porsch, H.; Bernert, B.; Mehic, M.; Theocharis, A.D.; Heldin, C.-H.; Heldin, P. Efficient TGF $\beta$-induced epithelial-mesenchymal transition depends on hyaluronan synthase HAS2. Oncogene 2013, 32, 4355-4365. [CrossRef] [PubMed]

34. Leight, J.L.; Wozniak, M.A.; Chen, S.; Lynch, M.L.; Chen, C.S. Matrix rigidity regulates a switch between TGF- $\beta 1$-induced apoptosis and epithelial-mesenchymal transition. Mol. Biol. Cell 2012, 23, 781-791. [CrossRef] [PubMed]

35. Varelas, X.; Wrana, J.L. Coordinating developmental signaling: Novel roles for the Hippo pathway. Trends Cell Biol. 2012, 22, 88-96. [CrossRef] [PubMed]

36. Wendt, M.K.; Taylor, M.A.; Schiemann, B.J.; Schiemann, W.P. Down-regulation of epithelial cadherin is required to initiate metastatic outgrowth of breast cancer. Mol. Biol. Cell 2011, 22, 2423-2435. [CrossRef] [PubMed]

37. Nieto, M.A. The ins and outs of the epithelial to mesenchymal transition in health and disease. Annu. Rev. Cell Dev. Biol. 2011, 27, 347-376. [CrossRef] [PubMed]

38. Schneider, D.J.; Wu, M.; Le, T.T.; Cho, S.H.; Brenner, M.B.; Blackburn, M.R.; Agarwal, S.K. Cadherin-11 contributes to pulmonary fibrosis: Potential role in TGF- $\beta$ production and epithelial to mesenchymal transition. FASEB J. 2012, 26, 503-512. [CrossRef] [PubMed]

39. Sancisi, V.; Gandolfi, G.; Ragazzi, M.; Nicoli, D.; Tamagnini, I.; Piana, S.; Ciarrocchi, A. Cadherin 6 is a new RUNX2 target in TGF- $\beta$ signalling pathway. PLoS ONE 2013, 8, e75489. [CrossRef] [PubMed]

40. Viloria-Petit, A.M.; Wrana, J.L. The TGF $\beta$-Par6 polarity pathway: Linking the Par complex to EMT and breast cancer progression. Cell Cycle 2010, 9, 623-624. [CrossRef] [PubMed]

41. Whiteman, E.L.; Liu, C.J.; Fearon, E.R.; Margolis, B. The transcription factor snail represses Crumbs3 expression and disrupts apico-basal polarity complexes. Oncogene 2008, 27, 3875-3879. [CrossRef] [PubMed]

42. Yu, L.; Liu, X.; Cui, K.; Di, Y.; Xin, L.; Sun, X.; Zhang, W.; Yang, X.; Wei, M.; Yao, Z.; et al. SND1 Acts Downstream of TGF $\beta 1$ and Upstream of Smurf1 to Promote Breast Cancer Metastasis. Cancer Res. 2015, 75, 1275-1286. [CrossRef] [PubMed]

43. Kong, W.; Yang, H.; He, L.; Zhao, J.J.; Coppola, D.; Dalton, W.S.; Cheng, J.Q. MicroRNA-155 is regulated by the transforming growth factor $\beta /$ Smad pathway and contributes to epithelial cell plasticity by targeting RhoA. Mol. Cell. Biol. 2008, 28, 6773-6784. [CrossRef] [PubMed]

44. Zhou, Q.; Fan, J.; Ding, X.; Peng, W.; Yu, X.; Chen, Y.; Nie, J. TGF- $\beta$-induced MiR-491-5p expression promotes Par-3 degradation in rat proximal tubular epithelial cells. J. Biol. Chem. 2010, 285, 40019-40027. [CrossRef] [PubMed]

45. Kowanetz, M.; Lönn, P.; Vanlandewijck, M.; Kowanetz, K.; Heldin, C.-H.; Moustakas, A. TGF $\beta$ induces SIK to negatively regulate type I receptor kinase signaling. J. Cell Biol. 2008, 182, 655-662. [CrossRef] [PubMed]

46. Lönn, P.; Vanlandewijck, M.; Raja, E.; Kowanetz, M.; Watanabe, Y.; Kowanetz, K.; Vasilaki, E.; Heldin, C.-H.; Moustakas, A. Transcriptional induction of salt-inducible kinase 1 by transforming growth factor $\beta$ leads to negative regulation of type I receptor signaling in cooperation with the Smurf2 ubiquitin ligase. J. Biol. Chem. 2012, 287, 12867-12878. [CrossRef] [PubMed]

47. Vanlandewijck, M.; Dadras, M.S.; Lomnytska, M.; Mahzabin, T.; Lee Miller, M.; Busch, C.; Brunak, S.; Heldin, C.-H.; Moustakas, A. The protein kinase SIK downregulates the polarity protein Par3. Oncotarget 2018, 9, 5716-5735. [CrossRef] [PubMed]

48. Parvani, J.G.; Galliher-Beckley, A.J.; Schiemann, B.J.; Schiemann, W.P. Targeted inactivation of b1 integrin induces b3 integrin switching, which drives breast cancer metastasis by TGF- $\beta$. Mol. Biol. Cell 2013, 24, 3449-3459. [CrossRef] [PubMed]

49. Pignatelli, J.; Tumbarello, D.A.; Schmidt, R.P.; Turner, C.E. Hic-5 promotes invadopodia formation and invasion during TGF- $\beta$-induced epithelial-mesenchymal transition. J. Cell Biol. 2012, 197, 421-437. [CrossRef] [PubMed] 
50. Papadimitriou, E.; Vasilaki, E.; Vorvis, C.; Iliopoulos, D.; Moustakas, A.; Kardassis, D.; Stournaras, C. Differential regulation of the two RhoA-specific GEF isoforms Net1/Net1A by TGF- $\beta$ and miR-24: Role in epithelial-to-mesenchymal transition. Oncogene 2012, 31, 2862-2875. [CrossRef] [PubMed]

51. Bhowmick, N.A.; Ghiassi, M.; Aakre, M.; Brown, K.; Singh, V.; Moses, H.L. TGF- $\beta$-induced RhoA and p160 ${ }^{\text {ROCK }}$ activation is involved in the inhibition of Cdc25A with resultant cell-cycle arrest. Proc. Natl. Acad. Sci. USA 2003, 100, 15548-15553. [CrossRef] [PubMed]

52. Abraham, C.G.; Ludwig, M.P.; Andrysik, Z.; Pandey, A.; Joshi, M.; Galbraith, M.D.; Sullivan, K.D.; Espinosa, J.M. DNp63a suppresses TGFB2 expression and RHOA activity to drive Ccll proliferation in squamous cell carcinomas. Cell Rep. 2018, 24, 3224-3236. [CrossRef] [PubMed]

53. Osborne, L.D.; Li, G.Z.; How, T.; O’Brien, E.T.; Blobe, G.C.; Superfine, R.; Mythreye, K. TGF- $\beta$ regulates LARG and GEF-H1 during EMT to affect stiffening response to force and cell invasion. Mol. Biol. Cell 2014, 25, 3528-3540. [CrossRef] [PubMed]

54. Ngan, E.; Northey, J.J.; Brown, C.M.; Ursini-Siegel, J.; Siegel, P.M. A complex containing LPP and $\alpha$-actinin mediates TGF $\beta$-induced migration and invasion of ErbB2-expressing breast cancer cells. J. Cell Sci. 2013, 126 Pt 9, 1981-1991. [CrossRef]

55. Haynes, J.; Srivastava, J.; Madson, N.; Wittmann, T.; Barber, D.L. Dynamic actin remodeling during epithelial-mesenchymal transition depends on increased moesin expression. Mol. Biol. Cell 2011, 22, 4750-4764. [CrossRef] [PubMed]

56. Mori, M.; Nakagami, H.; Koibuchi, N.; Miura, K.; Takami, Y.; Koriyama, H.; Hayashi, H.; Sabe, H.; Mochizuki, N.; Morishita, R.; et al. Zyxin mediates actin fiber reorganization in epithelial-mesenchymal transition and contributes to endocardial morphogenesis. Mol. Biol. Cell 2009, 20, 3115-3124. [CrossRef] [PubMed]

57. Mise, N.; Savai, R.; Yu, H.; Schwarz, J.; Kaminski, N.; Eickelberg, O. Zyxin is a transforming growth factor- $\beta$ (TGF- $\beta$ )/Smad 3 target gene that regulates lung cancer cell motility via integrin $\alpha 5 \beta 1$. J. Biol. Chem. 2012, 287, 31393-31405. [CrossRef] [PubMed]

58. Beach, J.R.; Hussey, G.S.; Miller, T.E.; Chaudhury, A.; Patel, P.; Monslow, J.; Zheng, Q.; Keri, R.A.; Reizes, O.; Bresnick, A.R.; et al. Myosin II isoform switching mediates invasiveness after TGF- $\beta$-induced epithelial-mesenchymal transition. Proc. Natl. Acad. Sci. USA 2011, 108, 17991-17996. [CrossRef] [PubMed]

59. Cantelli, G.; Orgaz, J.L.; Rodriguez-Hernandez, I.; Karagiannis, P.; Maiques, O.; Matias-Guiu, X.; Nestle, F.O.; Marti, R.M.; Karagiannis, S.N.; Sanz-Moreno, V. TGF- $\beta$-Induced Transcription Sustains Amoeboid Melanoma Migration and Dissemination. Curr. Biol. 2015, 25, 2899-2914. [CrossRef] [PubMed]

60. Scheel, C.; Eaton, E.N.; Li, S.H.J.; Chaffer, C.L.; Reinhardt, F.; Kah, K.J.; Bell, G.; Guo, W.; Rubin, J.; Richardson, A.L.; et al. Paracrine and Autocrine Signals Induce and Maintain Mesenchymal and Stem Cell States in the Breast. Cell 2011, 145, 926-940. [CrossRef] [PubMed]

61. Wendt, M.K.; Smith, J.A.; Schiemann, W.P. Transforming growth factor- $\beta$-induced epithelial-mesenchymal transition facilitates epidermal growth factor-dependent breast cancer progression. Oncogene 2010, 29, 6485-6498. [CrossRef] [PubMed]

62. Izumchenko, E.; Chang, X.; Michailidi, C.; Kagohara, L.; Ravi, R.; Paz, K.; Brait, M.; Hoque, M.O.; Ling, S.; Bedi, A.; et al. The TGF $\beta$-miR200-MIG6 pathway orchestrates the EMT-associated kinase switch that induces resistance to EGFR inhibitors. Cancer Res. 2014, 74, 3995-4005. [CrossRef] [PubMed]

63. Maitah, M.Y.; Ali, S.; Ahmad, A.; Gadgeel, S.; Sarkar, F.H. Up-regulation of sonic hedgehog contributes to TGF- $\beta 1$-induced epithelial to mesenchymal transition in NSCLC cells. PLoS ONE 2011, 6, e16068. [CrossRef] [PubMed]

64. Steinway, S.N.; Zanudo, J.G.; Ding, W.; Rountree, C.B.; Feith, D.J.; Loughran, T.P., Jr.; Albert, R. Network modeling of TGF $\beta$ signaling in hepatocellular carcinoma epithelial-to-mesenchymal transition reveals joint sonic hedgehog and Wnt pathway activation. Cancer Res. 2014, 74, 5963-5977. [CrossRef] [PubMed]

65. Gotzmann, J.; Mikula, M.; Eger, A.; Schulte-Hermann, R.; Foisner, R.; Beug, H.; Mikulits, W. Molecular aspects of epithelial cell plasticity: Implications for local tumor invasion and metastasis. Mutat. Res. 2004, 566, 9-20. [CrossRef]

66. Lahsnig, C.; Mikula, M.; Petz, M.; Zulehner, G.; Schneller, D.; van Zijl, F.; Huber, H.; Csiszar, A.; Beug, H.; Mikulits, W. ILEI requires oncogenic Ras for the epithelial to mesenchymal transition of hepatocytes and liver carcinoma progression. Oncogene 2009, 28, 638-650. [CrossRef] [PubMed] 
67. Van Zijl, F.; Mair, M.; Csiszar, A.; Schneller, D.; Zulehner, G.; Huber, H.; Eferl, R.; Beug, H.; Dolznig, H.; Mikulits, W. Hepatic tumor-stroma crosstalk guides epithelial to mesenchymal transition at the tumor edge. Oncogene 2009, 28, 4022-4033. [CrossRef] [PubMed]

68. Scheel, C.; Weinberg, R.A. Cancer stem cells and epithelial-mesenchymal transition: Concepts and molecular links. Semin. Cancer Biol. 2012, 22, 396-403. [CrossRef] [PubMed]

69. Thuault, S.; Valcourt, U.; Petersen, M.; Manfioletti, G.; Heldin, C.-H.; Moustakas, A. Transforming growth factor- $\beta$ employs HMGA2 to elicit epithelial-mesenchymal transition. J. Cell Biol. 2006, 174, 175-183. [CrossRef] [PubMed]

70. Thuault, S.; Tan, E.-J.; Peinado, H.; Cano, A.; Heldin, C.-H.; Moustakas, A. HMGA2 and Smads co-regulate SNAIL1 expression during induction of epithelial-to-mesenchymal transition. J. Biol. Chem. 2008, 283, 33437-33446. [CrossRef] [PubMed]

71. Vincent, T.; Neve, E.P.A.; Johnson, J.R.; Kukalev, A.; Rojo, F.; Albanell, J.; Pietras, K.; Virtanen, I.; Philipson, L.; Leopold, P.L.; et al. A SNAIL1-SMAD3/4 transcriptional repressor complex promotes TGF- $\beta$ mediated epithelial-mesenchymal transition. Nat. Cell Biol. 2009, 11, 943-950. [CrossRef] [PubMed]

72. Lin, T.; Ponn, A.; Hu, X.; Law, B.K.; Lu, J. Requirement of the histone demethylase LSD1 in Snai1-mediated transcriptional repression during epithelial-mesenchymal transition. Oncogene 2010, 29, 4896-4904. [CrossRef] [PubMed]

73. Lin, Y.; Wu, Y.; Li, J.; Dong, C.; Ye, X.; Chi, Y.I.; Evers, B.M.; Zhou, B.P. The SNAG domain of Snail1 functions as a molecular hook for recruiting lysine-specific demethylase 1. EMBO J. 2010, 29, 1803-1816. [CrossRef] [PubMed]

74. Tang, M.; Shen, H.; Jin, Y.; Lin, T.; Cai, Q.; Pinard, M.A.; Biswas, S.; Tran, Q.; Li, G.; Shenoy, A.K.; et al. The malignant brain tumor (MBT) domain protein SFMBT1 is an integral histone reader subunit of the LSD1 demethylase complex for chromatin association and epithelial-to-mesenchymal transition. J. Biol. Chem. 2013, 288, 27680-27691. [CrossRef] [PubMed]

75. Luo, H.; Shenoy, A.K.; Li, X.; Jin, Y.; Jin, L.; Cai, Q.; Tang, M.; Liu, Y.; Chen, H.; Reisman, D.; et al. MOF acetylates the histone demethylase LSD1 to suppress epithelial-to-mesenchymal transition. Cell Rep. 2016, 15, 2665-2678. [CrossRef] [PubMed]

76. Zhou, B.P.; Deng, J.; Xia, W.; Xu, J.; Li, Y.M.; Gunduz, M.; Hung, M.C. Dual regulation of Snail by GSK-3 $\beta$-mediated phosphorylation in control of epithelial-mesenchymal transition. Nat. Cell Biol. 2004, 6, 931-940. [CrossRef] [PubMed]

77. Lee, J.H.; Jung, S.M.; Yang, K.M.; Bae, E.; Ahn, S.G.; Park, J.S.; Seo, D.; Kim, M.; Ha, J.; Lee, J.; et al. A20 promotes metastasis of aggressive basal-like breast cancers through multi-monoubiquitylation of Snail1. Nat. Cell Biol. 2017, 19, 1260-1273. [CrossRef] [PubMed]

78. Estaràs, C.; Akizu, N.; Garcia, A.; Beltran, S.; de la Cruz, X.; Martinez-Balbas, M.A. Genome-wide analysis reveals that Smad3 and JMJD3 HDM co-activate the neural developmental program. Development 2012, 139, 2681-2691. [CrossRef] [PubMed]

79. Tang, B.; Qi, G.; Tang, F.; Yuan, S.; Wang, Z.; Liang, X.; Li, B.; Yu, S.; Liu, J.; Huang, Q.; et al. Aberrant JMJD3 expression upregulates Slug to promote migration, invasion, and stem cell-like behaviors in hepatocellular carcinoma. Cancer Res. 2016, 76, 6520-6532. [CrossRef] [PubMed]

80. Wang, W.L.; Huang, H.C.; Kao, S.H.; Hsu, Y.C.; Wang, Y.T.; Li, K.C.; Chen, Y.J.; Yu, S.L.; Wang, S.P.; Hsiao, T.H.; et al. Slug is temporally regulated by cyclin $\mathrm{E}$ in cell cycle and controls genome stability. Oncogene 2015, 34, 1116-1125. [CrossRef] [PubMed]

81. Yang, M.H.; Hsu, D.S.; Wang, H.W.; Wang, H.J.; Lan, H.Y.; Yang, W.H.; Huang, C.H.; Kao, S.Y.; Tzeng, C.H.; Tai, S.K.; et al. Bmi1 is essential in Twist1-induced epithelial-mesenchymal transition. Nat. Cell Biol. 2010, 12, 982-992. [CrossRef] [PubMed]

82. Li, C.W.; Xia, W.; Lim, S.O.; Hsu, J.L.; Huo, L.; Wu, Y.; Li, L.Y.; Lai, C.C.; Chang, S.S.; Hsu, Y.H.; et al. AKT1 inhibits epithelial-to-mesenchymal transition in breast cancer through phosphorylation-dependent Twist1 degradation. Cancer Res. 2016, 76, 1451-1462. [CrossRef] [PubMed]

83. Song, C.; Liu, W.; Li, J. USP17 is upregulated in osteosarcoma and promotes cell proliferation, metastasis, and epithelial-mesenchymal transition through stabilizing SMAD4. Tumour Biol. 2017, 39. [CrossRef] [PubMed]

84. Lin, Y.; Wang, Y.; Shi, Q.; Yu, Q.; Liu, C.; Feng, J.; Deng, J.; Evers, B.M.; Zhou, B.P.; Wu, Y. Stabilization of the transcription factors slug and twist by the deubiquitinase dub3 is a key requirement for tumor metastasis. Oncotarget 2017, 8, 75127-75140. [CrossRef] [PubMed] 
85. Lee, H.J.; Li, C.F.; Ruan, D.; Powers, S.; Thompson, P.A.; Frohman, M.A.; Chan, C.H. The DNA damage transducer RNF8 facilitates cancer chemoresistance and progression through Twist activation. Mol. Cell 2016, 63, 1021-1033. [CrossRef] [PubMed]

86. Yu, C.; Liu, Z.; Chen, Q.; Li, Y.; Jiang, L.; Zhang, Z.; Zhou, F. Nkx2.8 inhibits epithelial-mesenchymal transition in bladder urothelial carcinoma via transcriptional repression of Twist1. Cancer Res. 2018, 78, 1241-1252. [CrossRef] [PubMed]

87. Hu, J.; Tian, J.; Zhu, S.; Sun, L.; Yu, J.; Tian, H.; Dong, Q.; Luo, Q.; Jiang, N.; Niu, Y.; et al. Sox5 contributes to prostate cancer metastasis and is a master regulator of TGF- $\beta$-induced epithelial mesenchymal transition through controlling Twist1 expression. Br. J. Cancer 2018, 118, 88-97. [CrossRef] [PubMed]

88. Bakiri, L.; Macho-Maschler, S.; Custic, I.; Niemiec, J.; Guio-Carrion, A.; Hasenfuss, S.C.; Eger, A.; Muller, M.; Beug, H.; Wagner, E.F. Fra-1/AP-1 induces EMT in mammary epithelial cells by modulating Zeb1/2 and TGF $\beta$ expression. Cell Death Differ. 2015, 22, 336-350. [CrossRef] [PubMed]

89. Hou, P.; Li, L.; Chen, F.; Chen, Y.; Liu, H.; Li, J.; Bai, J.; Zheng, J. PTBP3-mediated regulation of ZEB1 mRNA stability promotes epithelial-mesenchymal transition in breast cancer. Cancer Res. 2018, 78, 387-398. [CrossRef] [PubMed]

90. Horiguchi, K.; Sakamoto, K.; Koinuma, D.; Semba, K.; Inoue, A.; Inoue, S.; Fujii, H.; Yamaguchi, A.; Miyazawa, K.; Miyazono, K.; et al. TGF- $\beta$ drives epithelial-mesenchymal transition through $\delta$ EF1-mediated downregulation of ESRP. Oncogene 2012, 31, 3190-3201. [CrossRef] [PubMed]

91. Chen, A.; Wong, C.S.; Liu, M.C.; House, C.M.; Sceneay, J.; Bowtell, D.D.; Thompson, E.W.; Moller, A. The ubiquitin ligase Siah is a novel regulator of Zeb1 in breast cancer. Oncotarget 2015, 6, 862-873. [CrossRef] [PubMed]

92. Preca, B.T.; Bajdak, K.; Mock, K.; Lehmann, W.; Sundararajan, V.; Bronsert, P.; Matzge-Ogi, A.; Orian-Rousseau, V.; Brabletz, S.; Brabletz, T.; et al. A novel ZEB1/HAS2 positive feedback loop promotes EMT in breast cancer. Oncotarget 2017, 8, 11530-11543. [CrossRef] [PubMed]

93. Bogachek, M.V.; De Andrade, J.P.; Weigel, R.J. Regulation of epithelial-mesenchymal transition through SUMOylation of transcription factors. Cancer Res. 2015, 75, 11-15. [CrossRef] [PubMed]

94. He, Y.; Northey, J.J.; Pelletier, A.; Kos, Z.; Meunier, L.; Haibe-Kains, B.; Mes-Masson, A.M.; Cote, J.F.; Siegel, P.M.; Lamarche-Vane, N. The Cdc42/Rac1 regulator CdGAP is a novel E-cadherin transcriptional co-repressor with Zeb2 in breast cancer. Oncogene 2017, 36, 3490-3503. [CrossRef] [PubMed]

95. Long, J.; Zuo, D.; Park, M. Pc2-mediated sumoylation of Smad-interacting protein 1 attenuates transcriptional repression of E-cadherin. J. Biol. Chem. 2005, 280, 35477-35489. [CrossRef] [PubMed]

96. Chang, H.; Liu, Y.; Xue, M.; Liu, H.; Du, S.; Zhang, L.; Wang, P. Synergistic action of master transcription factors controls epithelial-to-mesenchymal transition. Nucleic Acids Res. 2016, 44, 2514-2527. [CrossRef] [PubMed]

97. Kowanetz, M.; Valcourt, U.; Bergström, R.; Heldin, C.-H.; Moustakas, A. Id2 and Id3 define the potency of cell proliferation and differentiation responses to transforming growth factor $\beta$ and bone morphogenetic protein. Mol. Cell. Biol. 2004, 24, 4241-4254. [CrossRef] [PubMed]

98. Li, X.; Zhao, Z.; Zhang, X.; Yang, S.; Lin, X.; Yang, X.; Lin, X.; Shi, J.; Wang, S.; Zhao, W.; et al. Klf4 reduces stemness phenotype, triggers mesenchymal-epithelial transition (MET)-like molecular changes, and prevents tumor progression in nasopharygeal carcinoma. Oncotarget 2017, 8, 93924-93941. [CrossRef] [PubMed]

99. Mishra, V.K.; Subramaniam, M.; Kari, V.; Pitel, K.S.; Baumgart, S.J.; Naylor, R.M.; Nagarajan, S.; Wegwitz, F.; Ellenrieder, V.; Hawse, J.R.; et al. Kruppel-like transcription factor KLF10 suppresses TGF $\beta$-induced epithelial-to-mesenchymal transition via a negative feedback mechanism. Cancer Res. 2017, 77, 2387-2400. [CrossRef] [PubMed]

100. Burk, U.; Schubert, J.; Wellner, U.; Schmalhofer, O.; Vincan, E.; Spaderna, S.; Brabletz, T. A reciprocal repression between ZEB1 and members of the miR-200 family promotes EMT and invasion in cancer cells. EMBO Rep. 2008, 9, 582-589. [CrossRef] [PubMed]

101. Gregory, P.A.; Bert, A.G.; Paterson, E.L.; Barry, S.C.; Tsykin, A.; Farshid, G.; Vadas, M.A.; Khew-Goodall, Y.; Goodall, G.J. The miR-200 family and miR-205 regulate epithelial to mesenchymal transition by targeting ZEB1 and SIP1. Nat. Cell Biol. 2008, 10, 593-601. [CrossRef] [PubMed]

102. Korpal, M.; Lee, E.S.; Hu, G.; Kang, Y. The miR-200 family inhibits epithelial-mesenchymal transition and cancer cell migration by direct targeting of E-cadherin transcriptional repressors ZEB1 and ZEB2. J. Biol. Chem. 2008, 283, 14910-14914. [CrossRef] [PubMed] 
103. Gregory, P.A.; Bracken, C.P.; Smith, E.; Bert, A.G.; Wright, J.A.; Roslan, S.; Morris, M.; Wyatt, L.; Farshid, G.; Lim, Y.Y.; et al. An autocrine TGF- $\beta / Z E B / m i R-200$ signaling network regulates establishment and maintenance of epithelial-mesenchymal transition. Mol. Biol. Cell 2011, 22, 1686-1698. [CrossRef] [PubMed]

104. Wu, W.S.; You, R.I.; Cheng, C.C.; Lee, M.C.; Lin, T.Y.; Hu, C.T. Snail collaborates with EGR-1 and SP-1 to directly activate transcription of MMP 9 and ZEB1. Sci. Rep. 2017, 7, 17753. [CrossRef] [PubMed]

105. Díaz-López, A.; Diaz-Martin, J.; Moreno-Bueno, G.; Cuevas, E.P.; Santos, V.; Olmeda, D.; Portillo, F.; Palacios, J.; Cano, A. Zeb1 and Snail1 engage miR-200f transcriptional and epigenetic regulation during EMT. Int. J. Cancer 2015, 136, E62-E73. [CrossRef] [PubMed]

106. Sciacovelli, M.; Goncalves, E.; Johnson, T.I.; Zecchini, V.R.; da Costa, A.S.; Gaude, E.; Drubbel, A.V.; Theobald, S.J.; Abbo, S.R.; Tran, M.G.; et al. Fumarate is an epigenetic modifier that elicits epithelial-to-mesenchymal transition. Nature 2016, 537, 544-547. [CrossRef] [PubMed]

107. Siemens, H.; Jackstadt, R.; Hunten, S.; Kaller, M.; Menssen, A.; Gotz, U.; Hermeking, H. miR-34 and SNAIL form a double-negative feedback loop to regulate epithelial-mesenchymal transitions. Cell Cycle 2011, 10, 4256-4271. [CrossRef] [PubMed]

108. Wang, X.; Yu, M.; Zhao, K.; He, M.; Ge, W.; Sun, Y.; Wang, Y.; Sun, H.; Hu, Y. Upregulation of MiR-205 under hypoxia promotes epithelial-mesenchymal transition by targeting ASPP2. Cell Death Dis. 2016, 7, e2517. [CrossRef] [PubMed]

109. Kwak, S.Y.; Yoo, J.O.; An, H.J.; Bae, I.H.; Park, M.J.; Kim, J.; Han, Y.H. miR-5003-3p promotes epithelial-mesenchymal transition in breast cancer cells through Snail stabilization and direct targeting of E-cadherin. J. Mol. Cell Biol. 2016, 8, 372-383. [CrossRef] [PubMed]

110. Avalle, L.; Incarnato, D.; Savino, A.; Gai, M.; Marino, F.; Pensa, S.; Barbieri, I.; Stadler, M.B.; Provero, P.; Oliviero, S.; et al. MicroRNAs-143 and -145 induce epithelial to mesenchymal transition and modulate the expression of junction proteins. Cell Death Differ. 2017, 24, 1750-1760. [CrossRef] [PubMed]

111. Xu, M.; Li, J.; Wang, X.; Meng, S.; Shen, J.; Wang, S.; Xu, X.; Xie, B.; Liu, B.; Xie, L. MiR-22 suppresses epithelial-mesenchymal transition in bladder cancer by inhibiting Snail and MAPK1/Slug/vimentin feedback loop. Cell Death Dis. 2018, 9, 209. [CrossRef] [PubMed]

112. Bucay, N.; Bhagirath, D.; Sekhon, K.; Yang, T.; Fukuhara, S.; Majid, S.; Shahryari, V.; Tabatabai, Z.; Greene, K.L.; Hashimoto, Y.; et al. A novel microRNA regulator of prostate cancer epithelial-mesenchymal transition. Cell Death Differ. 2017, 24, 1263-1274. [CrossRef] [PubMed]

113. Chen, D.; Dang, B.L.; Huang, J.Z.; Chen, M.; Wu, D.; Xu, M.L.; Li, R.; Yan, G.R. MiR-373 drives the epithelial-to-mesenchymal transition and metastasis via the miR-373-TXNIP-HIF1a-TWIST signaling axis in breast cancer. Oncotarget 2015, 6, 32701-32712. [PubMed]

114. Xu, M.; Zhu, C.; Zhao, X.; Chen, C.; Zhang, H.; Yuan, H.; Deng, R.; Dou, J.; Wang, Y.; Huang, J.; et al. Atypical ubiquitin E3 ligase complex Skp1-Pam-Fbxo45 controls the core epithelial-to-mesenchymal transition-inducing transcription factors. Oncotarget 2015, 6, 979-994. [CrossRef] [PubMed]

115. Drasin, D.J.; Guarnieri, A.L.; Neelakantan, D.; Kim, J.; Cabrera, J.H.; Wang, C.A.; Zaberezhnyy, V.; Gasparini, P.; Cascione, L.; Huebner, K.; et al. TWIST1-induced miR-424 reversibly drives mesenchymal programming while inhibiting tumor initiation. Cancer Res. 2015, 75, 1908-1921. [CrossRef] [PubMed]

116. Richards, E.J.; Zhang, G.; Li, Z.P.; Permuth-Wey, J.; Challa, S.; Li, Y.; Kong, W.; Dan, S.; Bui, M.M.; Coppola, D.; et al. Long non-coding RNAs (LncRNA) regulated by transforming growth factor (TGF) $\beta$ : LncRNA-hit-mediated TGF $\beta$-induced epithelial to mesenchymal transition in mammary epithelia. J. Biol. Chem. 2015, 290, 6857-6867. [CrossRef] [PubMed]

117. Yuan, J.H.; Yang, F.; Wang, F.; Ma, J.Z.; Guo, Y.J.; Tao, Q.F.; Liu, F.; Pan, W.; Wang, T.T.; Zhou, C.C.; et al. A long noncoding RNA activated by TGF- $\beta$ promotes the invasion-metastasis cascade in hepatocellular carcinoma. Cancer Cell 2014, 25, 666-681. [CrossRef] [PubMed]

118. Fan, Y.; Shen, B.; Tan, M.; Mu, X.; Qin, Y.; Zhang, F.; Liu, Y. TGF- $\beta$-Induced Upregulation of malat1 Promotes Bladder Cancer Metastasis by Associating with suz12. Clin. Cancer Res. 2014, 20, 1531-1541. [CrossRef] [PubMed]

119. Chaudhury, A.; Hussey, G.S.; Ray, P.S.; Jin, G.; Fox, P.L.; Howe, P.H. TGF- $\beta$-mediated phosphorylation of hnRNP E1 induces EMT via transcript-selective translational induction of Dab2 and ILEI. Nat. Cell Biol. 2010, 12, 286-293. [CrossRef] [PubMed] 
120. Hussey, G.S.; Chaudhury, A.; Dawson, A.E.; Lindner, D.J.; Knudsen, C.R.; Wilce, M.C.; Merrick, W.C.; Howe, P.H. Identification of an mRNP complex regulating tumorigenesis at the translational elongation step. Mol. Cell 2011, 41, 419-431. [CrossRef] [PubMed]

121. Howley, B.V.; Hussey, G.S.; Link, L.A.; Howe, P.H. Translational regulation of inhibin betaA by TGF $\beta$ via the RNA-binding protein hnRNP E1 enhances the invasiveness of epithelial-to-mesenchymal transitioned cells. Oncogene 2016, 35, 1725-1735. [CrossRef] [PubMed]

122. Hussey, G.S.; Link, L.A.; Brown, A.S.; Howley, B.V.; Chaudhury, A.; Howe, P.H. Establishment of a TGF $\beta$-induced post-transcriptional EMT gene signature. PLoS ONE 2012, 7, e52624. [CrossRef] [PubMed]

123. Massagué, J.; Obenauf, A.C. Metastatic colonization by circulating tumour cells. Nature 2016, 529, $298-306$. [CrossRef] [PubMed]

124. Labelle, M.; Begum, S.; Hynes, R.O. Direct signaling between platelets and cancer cells induces an epithelial-mesenchymal-like transition and promotes metastasis. Cancer Cell 2011, 20, 576-590. [CrossRef] [PubMed]

125. Luo, W.; Tan, P.; Rodriguez, M.; He, L.; Tan, K.; Zeng, L.; Siwko, S.; Liu, M. Leucine-rich repeat-containing G protein-coupled receptor 4 (Lgr4) is necessary for prostate cancer metastasis via epithelial-mesenchymal transition. J. Biol. Chem. 2017, 292, 15525-15537. [CrossRef] [PubMed]

126. Okita, Y.; Kimura, M.; Xie, R.; Chen, C.; Shen, L.T.; Kojima, Y.; Suzuki, H.; Muratani, M.; Saitoh, M.; Semba, K.; et al. The transcription factor MAFK induces EMT and malignant progression of triple-negative breast cancer cells through its target GPNMB. Sci. Signal. 2017, 10. [CrossRef] [PubMed]

127. Canesin, G.; Cuevas, E.P.; Santos, V.; Lopez-Menendez, C.; Moreno-Bueno, G.; Huang, Y.; Csiszar, K.; Portillo, F.; Peinado, H.; Lyden, D.; et al. Lysyl oxidase-like 2 (LOXL2) and E47 EMT factor: Novel partners in E-cadherin repression and early metastasis colonization. Oncogene 2015, 34, 951-964. [CrossRef] [PubMed]

128. Tan, X.; Banerjee, P.; Liu, X.; Yu, J.; Gibbons, D.L.; Wu, P.; Scott, K.L.; Diao, L.; Zheng, X.; Wang, J.; et al. The epithelial-to-mesenchymal transition activator ZEB1 initiates a prometastatic competing endogenous RNA network. J. Clin. Investig. 2018, 128, 3198. [CrossRef] [PubMed]

129. Tan, X.; Banerjee, P.; Liu, X.; Yu, J.; Gibbons, D.L.; Wu, P.; Scott, K.L.; Diao, L.; Zheng, X.; Wang, J.; et al. The epithelial-to-mesenchymal transition activator ZEB1 initiates a prometastatic competing endogenous RNA network. J. Clin. Investig. 2018, 128, 1267-1282. [CrossRef] [PubMed]

130. Maturi, V.; Enroth, S.; Heldin, C.-H.; Moustakas, A. Genome-wide binding of transcription factor ZEB1 in triple-negative breast cancer cells. J. Cell. Physiol. 2018, 233, 7113-7127. [CrossRef] [PubMed]

131. Maturi, V.; Moren, A.; Enroth, S.; Heldin, C.-H.; Moustakas, A. Genomewide binding of transcription factor Snail1 in triple-negative breast cancer cells. Mol. Oncol. 2018, 12, 1153-1174. [CrossRef] [PubMed]

132. Fischer, K.R.; Durrans, A.; Lee, S.; Sheng, J.; Li, F.; Wong, S.T.; Choi, H.; El Rayes, T.; Ryu, S.; Troeger, J.; et al. Epithelial-to-mesenchymal transition is not required for lung metastasis but contributes to chemoresistance. Nature 2015, 527, 472-476. [CrossRef] [PubMed]

133. Zheng, X.; Carstens, J.L.; Kim, J.; Scheible, M.; Kaye, J.; Sugimoto, H.; Wu, C.C.; LeBleu, V.S.; Kalluri, R. Epithelial-to-mesenchymal transition is dispensable for metastasis but induces chemoresistance in pancreatic cancer. Nature 2015, 527, 525-530. [CrossRef] [PubMed]

134. Krebs, A.M.; Mitschke, J.; Lasierra Losada, M.; Schmalhofer, O.; Boerries, M.; Busch, H.; Boettcher, M.; Mougiakakos, D.; Reichardt, W.; Bronsert, P.; et al. The EMT-activator Zeb1 is a key factor for cell plasticity and promotes metastasis in pancreatic cancer. Nat. Cell Biol. 2017, 19, 518-529. [CrossRef] [PubMed]

135. Aiello, N.M.; Brabletz, T.; Kang, Y.; Nieto, M.A.; Weinberg, R.A.; Stanger, B.Z. Upholding a role for EMT in pancreatic cancer metastasis. Nature 2017, 547, E7-E8. [CrossRef] [PubMed]

136. Ye, X.; Brabletz, T.; Kang, Y.; Longmore, G.D.; Nieto, M.A.; Stanger, B.Z.; Yang, J.; Weinberg, R.A. Upholding a role for EMT in breast cancer metastasis. Nature 2017, 547, E1-E3. [CrossRef] [PubMed]

137. Zajac, O.; Raingeaud, J.; Libanje, F.; Lefebvre, C.; Sabino, D.; Martins, I.; Roy, P.; Benatar, C.; Canet-Jourdan, C.; Azorin, P.; et al. Tumour spheres with inverted polarity drive the formation of peritoneal metastases in patients with hypermethylated colorectal carcinomas. Nat. Cell Biol. 2018, 20, 296-306. [CrossRef] [PubMed]

138. Pastushenko, I.; Brisebarre, A.; Sifrim, A.; Fioramonti, M.; Revenco, T.; Boumahdi, S.; Van Keymeulen, A.; Brown, D.; Moers, V.; Lemaire, S.; et al. Identification of the tumour transition states occurring during EMT. Nature 2018, 556, 463-468. [CrossRef] [PubMed] 
139. Xu, Y.; Lee, D.K.; Feng, Z.; Xu, Y.; Bu, W.; Li, Y.; Liao, L.; Xu, J. Breast tumor cell-specific knockout of Twist1 inhibits cancer cell plasticity, dissemination, and lung metastasis in mice. Proc. Natl. Acad. Sci. USA 2017, 114, 11494-11499. [CrossRef] [PubMed]

140. Pickup, M.; Novitskiy, S.; Moses, H.L. The roles of TGF $\beta$ in the tumour microenvironment. Nat. Rev. Cancer 2013, 13, 788-799. [CrossRef] [PubMed]

141. Stankic, M.; Pavlovic, S.; Chin, Y.; Brogi, E.; Padua, D.; Norton, L.; Massagué, J.; Benezra, R. TGF- $\beta$-Id1 Signaling Opposes Twist1 and Promotes Metastatic Colonization via a Mesenchymal-to-Epithelial Transition. Cell Rep. 2013, 5, 1228-1242. [CrossRef] [PubMed]

142. Calon, A.; Espinet, E.; Palomo-Ponce, S.; Tauriello, D.V.; Iglesias, M.; Cespedes, M.V.; Sevillano, M.; Nadal, C.; Jung, P.; Zhang, X.H.; et al. Dependency of colorectal cancer on a TGF- $\beta$-driven program in stromal cells for metastasis initiation. Cancer Cell 2012, 22, 571-584. [CrossRef] [PubMed]

143. Kang, Y.; Siegel, P.M.; Shu, W.; Drobnjak, M.; Kakonen, S.M.; Cordon-Cardo, C.; Guise, T.A.; Massagué, J. A multigenic program mediating breast cancer metastasis to bone. Cancer Cell 2003, 3, 537-549. [CrossRef]

144. Fournier, P.G.; Juarez, P.; Jiang, G.; Clines, G.A.; Niewolna, M.; Kim, H.S.; Walton, H.W.; Peng, X.H.; Liu, Y.; Mohammad, K.S.; et al. The TGF- $\beta$ signaling regulator PMEPA1 suppresses prostate cancer metastases to bone. Cancer Cell 2015, 27, 809-821. [CrossRef] [PubMed]

145. Padua, D.; Zhang, X.H.; Wang, Q.; Nadal, C.; Gerald, W.L.; Gomis, R.R.; Massagué, J. TGF $\beta$ primes breast tumors for lung metastasis seeding through angiopoietin-like 4. Cell 2008, 133, 66-77. [CrossRef] [PubMed]

146. Yang, L.; Huang, J.; Ren, X.; Gorska, A.E.; Chytil, A.; Aakre, M.; Carbone, D.P.; Matrisian, L.M.; Richmond, A.; Lin, P.C.; et al. Abrogation of TGF $\beta$ signaling in mammary carcinomas recruits Gr- $1^{+} \mathrm{CD} 11 \mathrm{~b}^{+}$myeloid cells that promote metastasis. Cancer Cell 2008, 13, 23-35. [CrossRef] [PubMed]

147. Wolf, K.; Alexander, S.; Schacht, V.; Coussens, L.M.; von Andrian, U.H.; van Rheenen, J.; Deryugina, E.; Friedl, P. Collagen-based cell migration models in vitro and in vivo. Semin. Cell Dev. Biol. 2009, 20, 931-941. [CrossRef] [PubMed]

148. Friedl, P.; Sahai, E.; Weiss, S.; Yamada, K.M. New dimensions in cell migration. Nat. Rev. Mol. Cell Biol. 2012, 13, 743-747. [CrossRef] [PubMed]

149. Weigelt, B.; Ghajar, C.M.; Bissell, M.J. The need for complex 3D culture models to unravel novel pathways and identify accurate biomarkers in breast cancer. Adv. Drug Deliv. Rev. 2014, 69-70, 42-51. [CrossRef] [PubMed]

150. Furuta, S.; Ren, G.; Mao, J.H.; Bissell, M.J. Laminin signals initiate the reciprocal loop that informs breast-specific gene expression and homeostasis by activating NO, p53 and microRNAs. eLife 2018, 7, e26148. [CrossRef] [PubMed]

151. Weigelin, B.; Bakker, G.J.; Friedl, P. Third harmonic generation microscopy of cells and tissue organization. J. Cell Sci. 2016, 129, 245-255. [CrossRef] [PubMed]

152. Entenberg, D.; Pastoriza, J.M.; Oktay, M.H.; Voiculescu, S.; Wang, Y.; Sosa, M.S.; Aguirre-Ghiso, J.; Condeelis, J. Time-lapsed, large-volume, high-resolution intravital imaging for tissue-wide analysis of single cell dynamics. Methods 2017, 128, 65-77. [CrossRef] [PubMed]

153. Imamura, T.; Saitou, T.; Kawakami, R. In vivo optical imaging of cancer cell function and tumor microenvironment. Cancer Sci. 2018, 109, 912-918. [CrossRef] [PubMed]

154. Harper, K.L.; Sosa, M.S.; Entenberg, D.; Hosseini, H.; Cheung, J.F.; Nobre, R.; Avivar-Valderas, A.; Nagi, C.; Girnius, N.; Davis, R.J.; et al. Mechanism of early dissemination and metastasis in Her2 ${ }^{+}$mammary cancer. Nature 2016, 540, 588-592. [CrossRef] [PubMed]

155. Kubota, S.I.; Takahashi, K.; Nishida, J.; Morishita, Y.; Ehata, S.; Tainaka, K.; Miyazono, K.; Ueda, H.R. Whole-body profiling of cancer metastasis with single-cell resolution. Cell Rep. 2017, 20, 236-250. [CrossRef] [PubMed]

156. Ocana, O.H.; Corcoles, R.; Fabra, A.; Moreno-Bueno, G.; Acloque, H.; Vega, S.; Barrallo-Gimeno, A.; Cano, A.; Nieto, M.A. Metastatic colonization requires the repression of the epithelial-mesenchymal transition inducer Prrx1. Cancer Cell 2012, 22, 709-724. [CrossRef] [PubMed]

157. Korpal, M.; Ell, B.J.; Buffa, F.M.; Ibrahim, T.; Blanco, M.A.; Celia-Terrassa, T.; Mercatali, L.; Khan, Z.; Goodarzi, H.; Hua, Y.; et al. Direct targeting of Sec23a by miR-200s influences cancer cell secretome and promotes metastatic colonization. Nat. Med. 2011, 17, 1101-1108. [CrossRef] [PubMed] 
158. Banno, A.; Garcia, D.A.; van Baarsel, E.D.; Metz, P.J.; Fisch, K.; Widjaja, C.E.; Kim, S.H.; Lopez, J.; Chang, A.N.; Geurink, P.P.; et al. Downregulation of $26 \mathrm{~S}$ proteasome catalytic activity promotes epithelial-mesenchymal transition. Oncotarget 2016, 7, 21527-21541. [CrossRef] [PubMed]

159. Park, S.Y.; Kim, M.J.; Park, S.A.; Kim, J.S.; Min, K.N.; Kim, D.K.; Lim, W.; Nam, J.S.; Sheen, Y.Y. Combinatorial TGF- $\beta$ attenuation with paclitaxel inhibits the epithelial-to-mesenchymal transition and breast cancer stem-like cells. Oncotarget 2015, 6, 37526-37543. [CrossRef] [PubMed]

160. Smith, K.A.; Zhou, B.; Avdulov, S.; Benyumov, A.; Peterson, M.; Liu, Y.; Okon, A.; Hergert, P.; Braziunas, J.; Wagner, C.R.; et al. Transforming Growth Factor- $\beta 1$ Induced Epithelial Mesenchymal Transition is blocked by a chemical antagonist of translation factor eIF4E. Sci. Rep. 2015, 5, 18233. [CrossRef] [PubMed]

161. Wu, Y.; Fu, Y.; Zheng, L.; Lin, G.; Ma, J.; Lou, J.; Zhu, H.; He, Q.; Yang, B. Nutlin-3 inhibits epithelial-mesenchymal transition by interfering with canonical transforming growth factor- $\beta 1-S m a d-S n a i l / S l u g$ axis. Cancer Lett. 2014, 342, 82-91. [CrossRef] [PubMed]

162. Termén, S.; Tan, E.-J.; Heldin, C.-H.; Moustakas, A. p53 regulates epithelial-mesenchymal transition induced by transforming growth factor $\beta$. J. Cell. Physiol. 2013, 228, 801-813. [CrossRef] [PubMed]

163. Han, D.; Wu, G.; Chang, C.; Zhu, F.; Xiao, Y.; Li, Q.; Zhang, T.; Zhang, L. Disulfiram inhibits TGF- $\beta$-induced epithelial-mesenchymal transition and stem-like features in breast cancer via ERK/NF-kB/Snail pathway. Oncotarget 2015, 6, 40907-40919. [CrossRef] [PubMed]

164. Sakamoto, T.; Kobayashi, S.; Yamada, D.; Nagano, H.; Tomokuni, A.; Tomimaru, Y.; Noda, T.; Gotoh, K.; Asaoka, T.; Wada, H.; et al. A Histone Deacetylase Inhibitor Suppresses Epithelial-Mesenchymal Transition and Attenuates Chemoresistance in Biliary Tract Cancer. PLoS ONE 2016, 11, e0145985. [CrossRef] [PubMed]

165. Fukuchi, M.; Imamura, T.; Chiba, T.; Ebisawa, T.; Kawabata, M.; Tanaka, K.; Miyazono, K. Ligand-dependent degradation of Smad3 by a ubiquitin ligase complex of ROC1 and associated proteins. Mol. Biol. Cell 2001, 12, 1431-1443. [CrossRef] [PubMed]

166. Fu, J.; Ke, X.; Tan, S.; Liu, T.; Wang, S.; Ma, J.; Lu, H. The natural compound codonolactone attenuates TGF- $\beta 1$-mediated epithelial-to-mesenchymal transition and motility of breast cancer cells. Oncol. Rep. 2016, 35, 117-126. [CrossRef] [PubMed]

167. Zhang, L.; Cheng, X.; Gao, Y.; Zhang, C.; Bao, J.; Guan, H.; Yu, H.; Lu, R.; Xu, Q.; Sun, Y. Curcumin inhibits metastasis in human papillary thyroid carcinoma BCPAP cells via down-regulation of the TGF- $\beta / \mathrm{Smad} 2 / 3$ signaling pathway. Exp. Cell Res. 2016, 341, 157-165. [CrossRef] [PubMed]

168. Wu, J.; Han, J.; Hou, B.; Deng, C.; Wu, H.; Shen, L. Sulforaphane inhibits TGF- $\beta$-induced epithelial-mesenchymal transition of hepatocellular carcinoma cells via the reactive oxygen species-dependent pathway. Oncol. Rep. 2016, 35, 2977-2983. [CrossRef] [PubMed] 